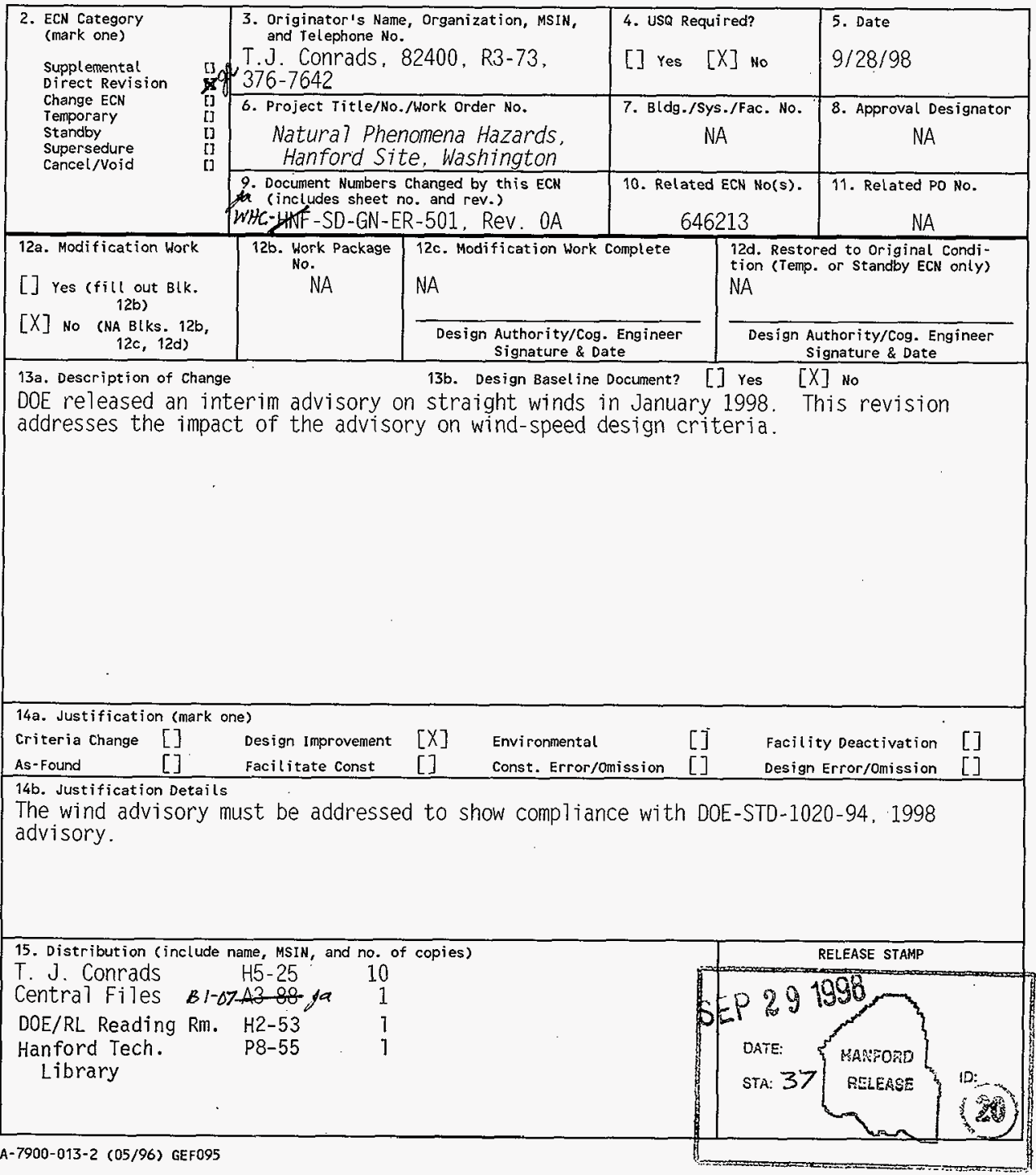




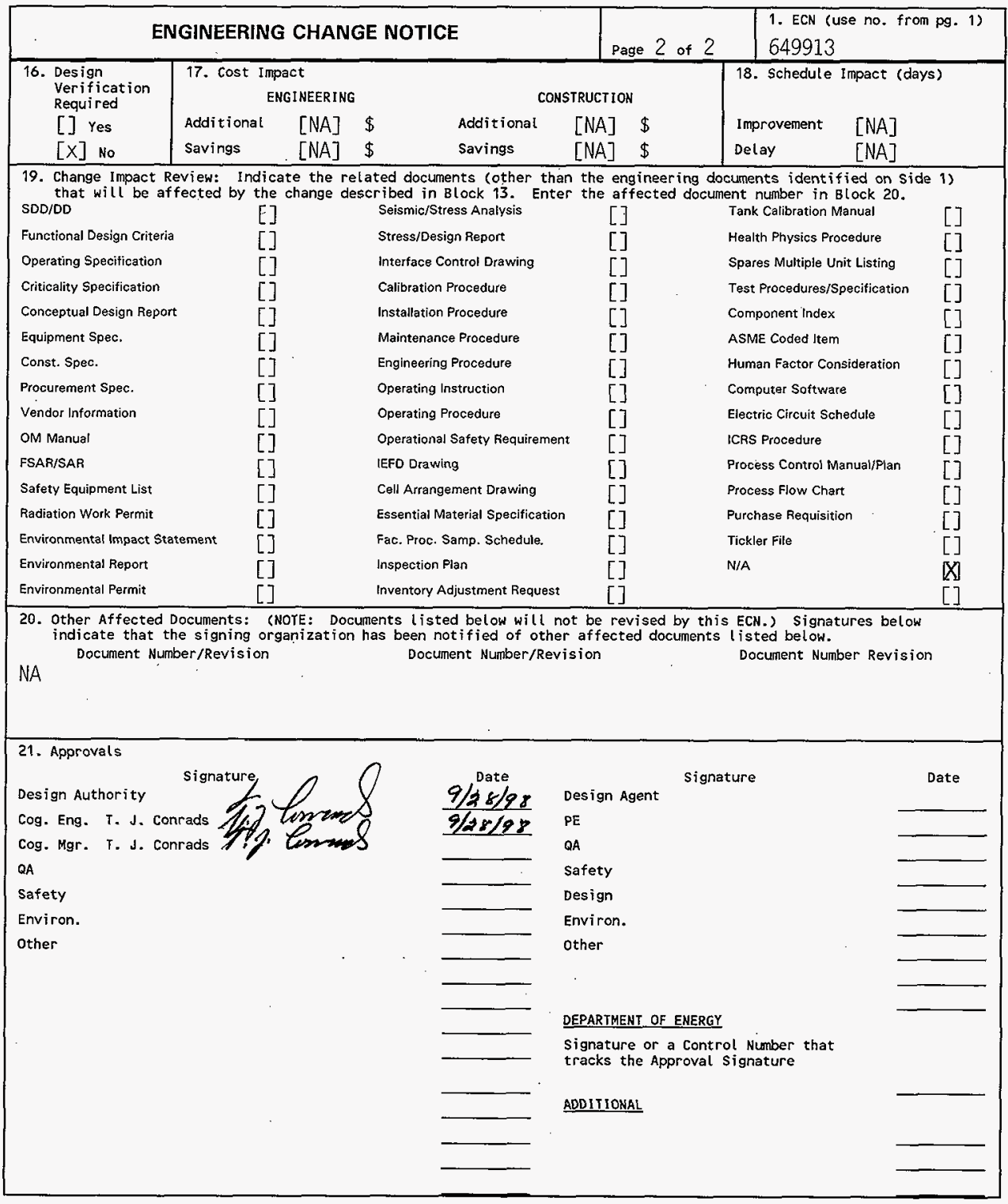




\section{Natural Phenomena Hazards, Hanford Site, Washington}

T. J. Conrads

NUMATEC Hanford Company, Richland, WA 99352

U.S. Department of Energy Contract DE-AC06-96RL13200

EDT/ECN: 614715/649913 UC: 2000

Org Code: 82400 Charge Code: D2D31/ HANA2600

B\&R Code: EW3130010 Total Pages: J 36

Key Words: Natural phenomena hazards, earthquake hazard, seismic hazard, volcano hazard, ash hazard, wind hazard, flood hazard

Abstract: This document presents the natural phenomena hazard loads for use in implementing DOE Order 5480.28. Natura 7 Phenomena Hazards

Mitigation, and supports development of double-shell tank systems

specifications at the Hanford Site in south-central Washington State.

The natural phenomena covered are seismic, flood, wind, volcanic ash,

lightning, snow, temperature, solar radiation, suspended sediment, and relative humidity.

TRADENARK DISCLAIMER. Reference herein to any specific cormercial product, process, or service by trade name, trademark, manufacturer, or otherwise, does not necessarily constitute or imply its endorsement, recommendation, or favoring by the United States Government or any agency thereof or its contractors or subcontractors.

Printed in the United States of America. To obtain copies of this document, contact: Docunent Control Services, P.0. Box 950, Mailstop H6-08, Richland WA 99352, Phone (509) 372-2420;

Fax (509) 376-4989.
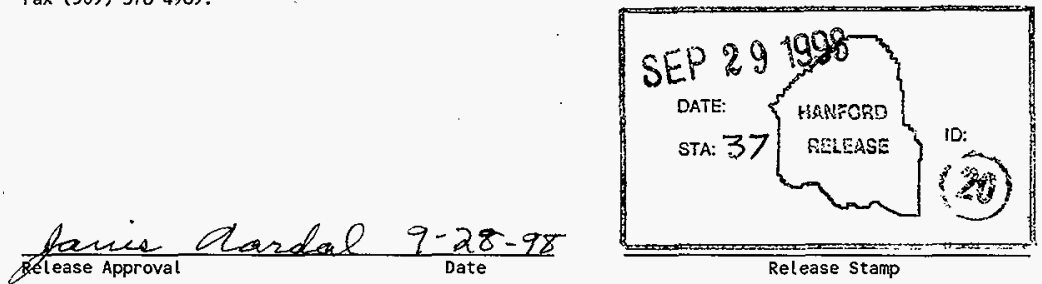
(2) Title

Natural Phenomena Hazards, Hanford Site, Washington

CHANGE CONTROL RECORD

(3) Revision

0

$0-A$
(7) EDT 61471, dated Apri1 16, 1996
(4) Description of Change - Replace, Add, and Delete Pages

A description of hail hazard at the Hanford Site is added to Section 6.0. Descriptions of ambient and subsurface temperature, solar radiation, atmospheric suspended sediment, and relative humidity are added as Sections 8.0,9.0,10.0, and 11.0 . Replace pp. iii and iv; remove pp. 21 through 24 and insert pp. 21 through 28. ECN-646273

1 RS Section 3.0, Wind Hazard, is revised to address an Interim Advisory on straightwind design criteria released by DOE January, 1998. A new Hanford Site wind hazard assesment is included and design wind-speeds are changed from fastest-mile to peak gusts ECN-649973

\begin{tabular}{l}
\hline \\
\hline \\
\hline \\
assesment is included and design wind-speeds \\
\hline ECN-649973 from fastest-mile to peak gusts
\end{tabular}

Authorized for Release

(5) cog. Engr. $\quad$ (6) Cog. Mgr. Date

T. J. Conrads R. P. Marshal1

T. J. fonrads R. P. Marshall

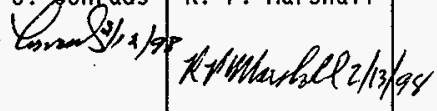

T.S. Gonrgds TJ.Cpn rads 
HNF-SD-GN-ER-501, Rev. 1

\section{CONTENTS}

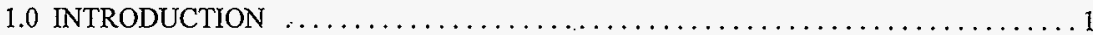

1.1 SITE HAZARD ASSESSMENTS $\ldots \ldots \ldots \ldots \ldots \ldots \ldots \ldots \ldots \ldots \ldots \ldots \ldots \ldots \ldots \ldots$

1.2 SITE DESIGN HAZARD LEVELS $\ldots \ldots \ldots \ldots \ldots \ldots \ldots \ldots \ldots \ldots \ldots$

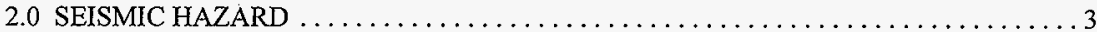

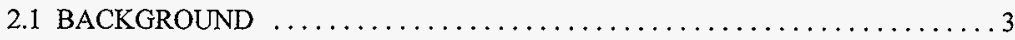

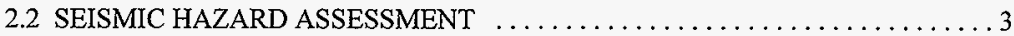

2.3 DESIGN-BASIS GROUND MOTION $\ldots \ldots \ldots \ldots \ldots \ldots \ldots \ldots \ldots \ldots$

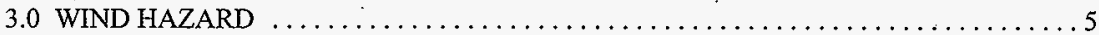

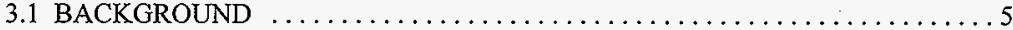

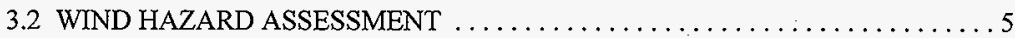

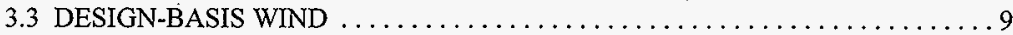

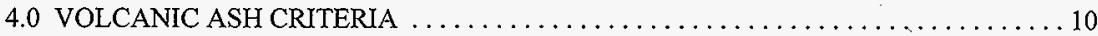

4.1 BACKGROUND ...................................... 10

4.2 VOLCANIC ASH HAZARD ASSESSMENT $\ldots \ldots \ldots \ldots \ldots \ldots \ldots \ldots \ldots \ldots \ldots \ldots \ldots$

4.3 DESIGN-BASIS ASH FALL $\ldots \ldots \ldots \ldots \ldots \ldots \ldots \ldots \ldots \ldots \ldots \ldots \ldots \ldots \ldots \ldots$

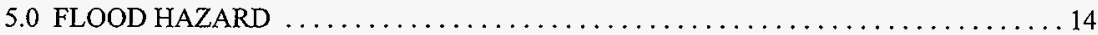

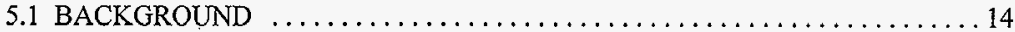

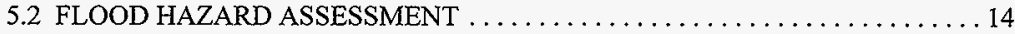

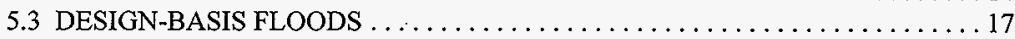

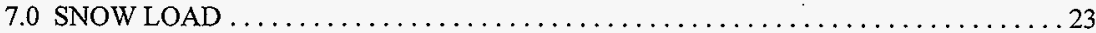

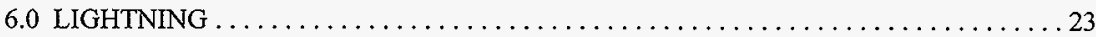

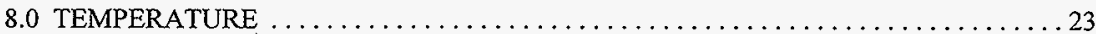

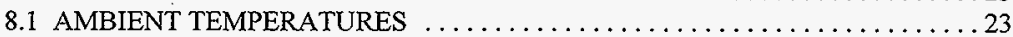

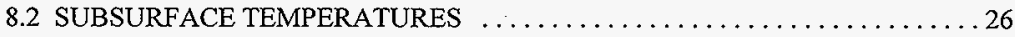

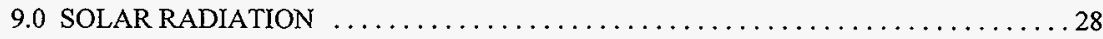

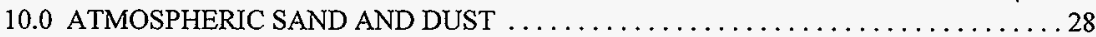

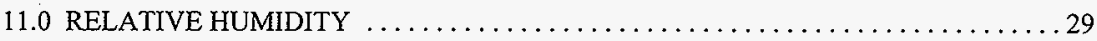

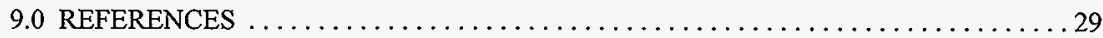




\section{LIST OF FIGURES}

1 Hanford Site Location Map. . ................................. 2

2 Seismic Hazard Curves . . . . . . . . . . . . . . . . . . . . . . . . . . . . . 4

3 Equal-Hazard 5-Percent Damped Response Spectra

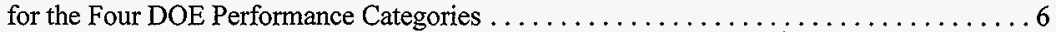

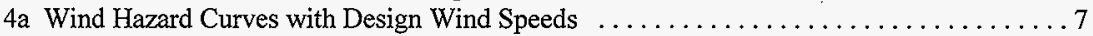

$4 \mathrm{~b}$ Hanford Meteorological Tower Peak Gust and Extreme Wind Speed Analyses . . . . . . . 8

5 Annual Probability of $1 \mathrm{~cm}$ or More of Volcanic Ash Accumulation in Washington and Oregon from Major Cascade Volcanoes $\ldots \ldots \ldots \ldots \ldots \ldots \ldots \ldots$

6 Annual Probability of $10 \mathrm{~cm}$ or More of Volcanic Ash Accumulation in Washington and Oregon from Major Cascade Volcanoes .................. 12

7 Cascade Range Volcanic Ash Hazard . . . . . . . . . . . . . . . . . . . . . . . . . . 13

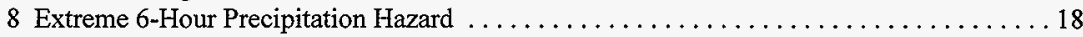

9 Fractile Hazard Curves for Peak Flood Elevation at N Reactor . . . . . . . . . . . . . . . . 19

10 Extent of Probable Maximum Flood in Cold Creek Area . . . . . . . . . . . . . . . 21

11 River Profiles for Each Performance Category . . . . . . . . . . . . . . . . . . . 22

12 Highest Temperature During Each of 66 Summers of Record at the Hanford Site . . . . . 24

13 Lowest Temperature During Each of 68 Winters at the Hanford Site:

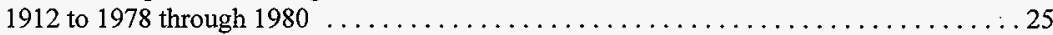

14 Annual Lowest Subsoil Temperatures (1955 Through 1980 [Stone et al. 1983]) . . . . . . . 27

15 Probability (Percent) that Maximum Subsoil Temperature

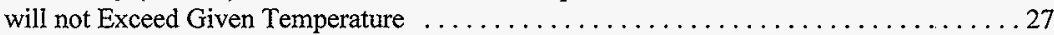

\section{LIST OF TABLES}

1 Seismic Hazard Exceedance Probabilities . . . . . . . . . . . . . . . . . . . . . . . . 5

2 Performance Category Wind Speeds, Hanford Site . . . . . . . . . . . . . . . . . 9

3 Straight Wind Design Criteria Measured as Peak Gusts . . . . . . . . . . . . . . . 10

4 Design-Basis Loads from Ashfall Criteria ............................ 11

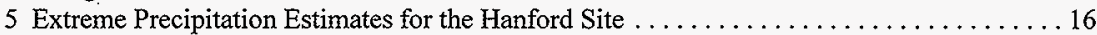

6 Design-Basis Precipitation Levels . . . . . . . . . . . . . . . . . . . . . . . . . 20

7 Approximate Elevations for Flooding Probabilities at $\mathrm{N}$ Reactor . . . . . . . . . . . 20

8 Maximum and Minimum Subsurface Temperatures at the Hanford Site $\ldots \ldots \ldots \ldots \ldots 26$

9 Temperature Range for Subsurface SSC Operation $\ldots \ldots \ldots \ldots \ldots \ldots \ldots \ldots \ldots \ldots \ldots$ 


\section{NATURAL PHENOMENA HAZARDS HANFORD SITE, WASHINGTON}

\subsection{INTRODUCTION}

This document presents the natural phenomena hazard (NPH) loads for use in implementing DOE Order 5480.28, Natural Phenomena Hazards Mitigation, at the Hanford Site in south-central Washington State. The purpose of this document is twofold.

- Summarize the NPH that are important to the design and evaluation of structures, systems, and components at the Hanford Site

- Develop the appropriate natural phenomena loads for use in the implementation of DOE Order 5480.28 .

The supporting standards, DOE-STD-1020-94, Natural Phenomena Hazards Design and Evaluation Criteria for Department of Energy Facilities (DOE 1994a); DOE-STD-1022-94, Natural Phenomena Hazards Site Characteristics Criteria (DOE 1994b); and DOE-STD-1023-95, Natural Phenomena Hazards Assessment Criteria (DOE 1995), are the basis for developing the NPH loads.

\subsection{SITE HAZARD ASSESSMENTS}

The hazards covered in this document are seismic, flood, wind, volcanic ash, lightning, and snow. Except for lightning and snow, the hazards are addressed in terms of the annual probabilities of exceeding discrete values. The bases for the probabilistic-based hazard values are summarized.

Except for seismic and flood hazards, the NPH are the same at all of the Hanford Site Areas: $100 \mathrm{~K}, 200$ West, 200 East, 300 , and 400 (Figure 1). The seismic hazard depends on the proximity of the site to potential earthquake sources and on the engineering properties of the soil. The river flooding hazard is directly related to site elevation and proximity to a river, while local storm runoff flooding is related to the site topography and constructed structures.

\subsection{SITE DESIGN HAZARD LEVELS}

DOE Order 5480.28 requires that each structure, system, and component be assigned to one of five performance categories with target performance goal probabilities. This performance goal serves as a measure of the level of the desired protection against potential hazards from natural phenomena. The performance goal is achieved by using the appropriate combination of design conservatism and NPH probability. This process is thoroughly discussed in

DOE-STD-1020-94. 
Figure 1. Hanford Site Location Map.

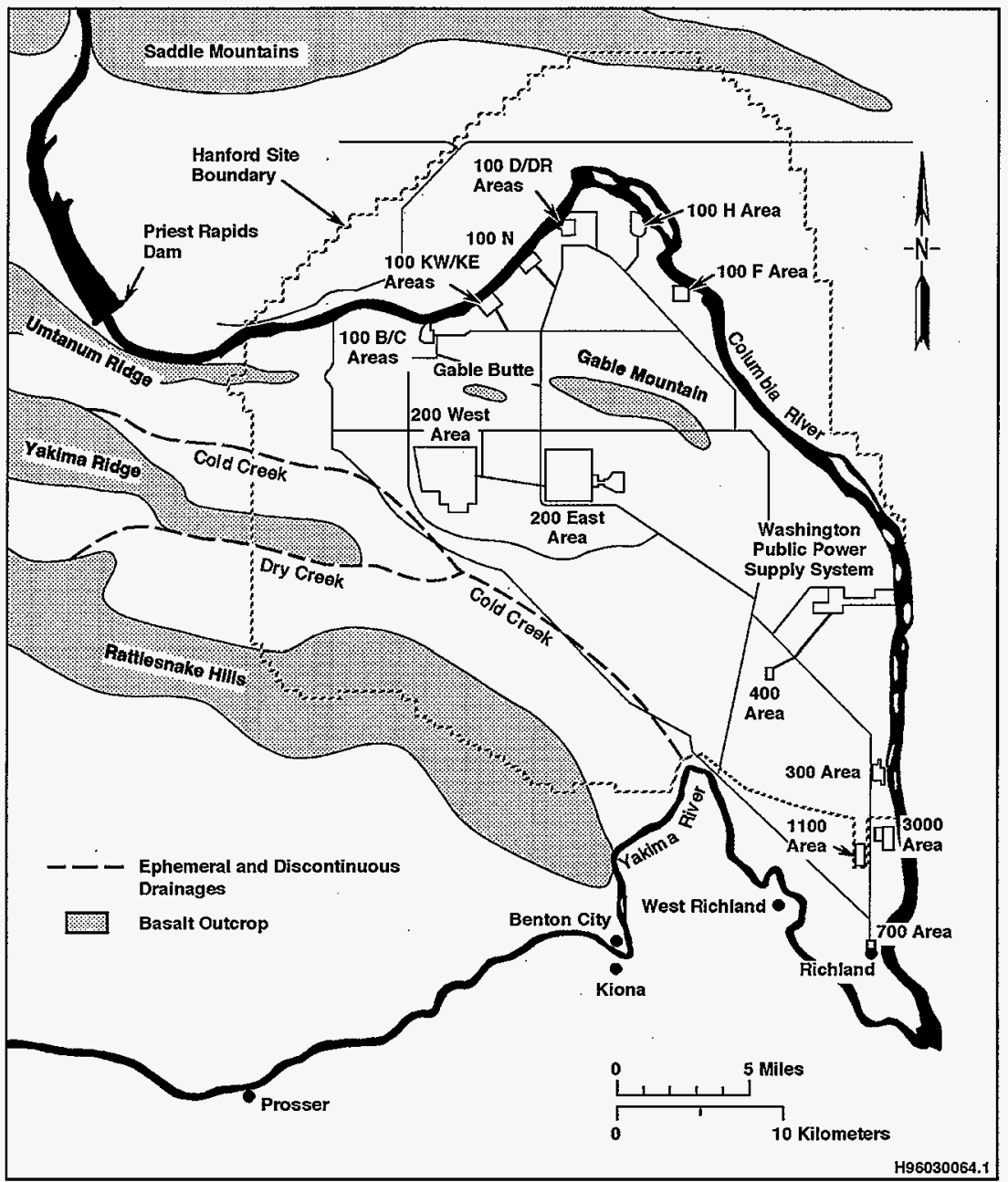




\subsection{SEISMIC HAZARD}

\subsection{BACKGROUND}

The Hanford Site lies in the Pasco Basin near the eastern limit of the Yakima Foldbelt. The Site is underlain by basalt of the Columbia River Basalt Group, which is covered by up to $213 \mathrm{~m}$ (700 ft) of relatively stiff sediments. It is in an area of low-magnitude seismicity and is under north-south compressional stress, which is reflected in the deformation of the Yakima folds. The following characteristics are major contributors to the seismic hazard in and around the Hanford Site:

- Fault sources related to the Yakima folds

- Shallow basalt sources that account for the observed seismicity within the Columbia River Basalt Group and not associated with the Yakima Folds

- Crystalline basement source region

- Cascadia Subduction Zone earthquakes.

\subsection{SEISMIC HAZARD ASSESSMENT}

A seismic hazard analysis was recently completed for the Hanford Site (Geomatrix 1996). Previous seismic hazard analyses were done for the Washington Public Power Supply System's (Supply System) WNP-1/4 and WNP/2, which also are located on the Hanford Site (Power et al. 1981). The Supply System study was later applied to the Hanford Site areas controlled by the U.S. Department of Energy (DOE) by Woodward-Clyde Consultants (WCC 1989).

The following seismic hazard values are based on the current seismic hazard study by Geomatrix (1996), which incorporates seismo-tectonic data and interpretations that postdate the Supply System's earlier assessment. The mean seismic hazard curves for the $100 \mathrm{~K}, 200$ West, 200 East, 300, and 400 Areas are shown in Figure 2. (See Geomatrix [1996] for details). The largest historical ground motion is estimated to be less than $0.03 \mathrm{~g}$ from the magnitude $5.7 \mathrm{~s} 1936$ Milton-Freewater, Oregon, earthquake.

\subsection{DESIGN-BASIS GROUND MOTION}

The seismic hazard exceedance probabilities for each performance category are derived in DOE-STD-1020-94 and presented in Table 1. See Figure 2 to determine the peak horizontal ground motion for each category at each of the five Hanford Site areas plotted. For more detail, including seismic source characterization, attenuation relationships, and Site response, see Geomatrix (1996). 
HNF-SD-GN-ER-501, Rev. 1

Figure 2. Seismic Hazard Curves.

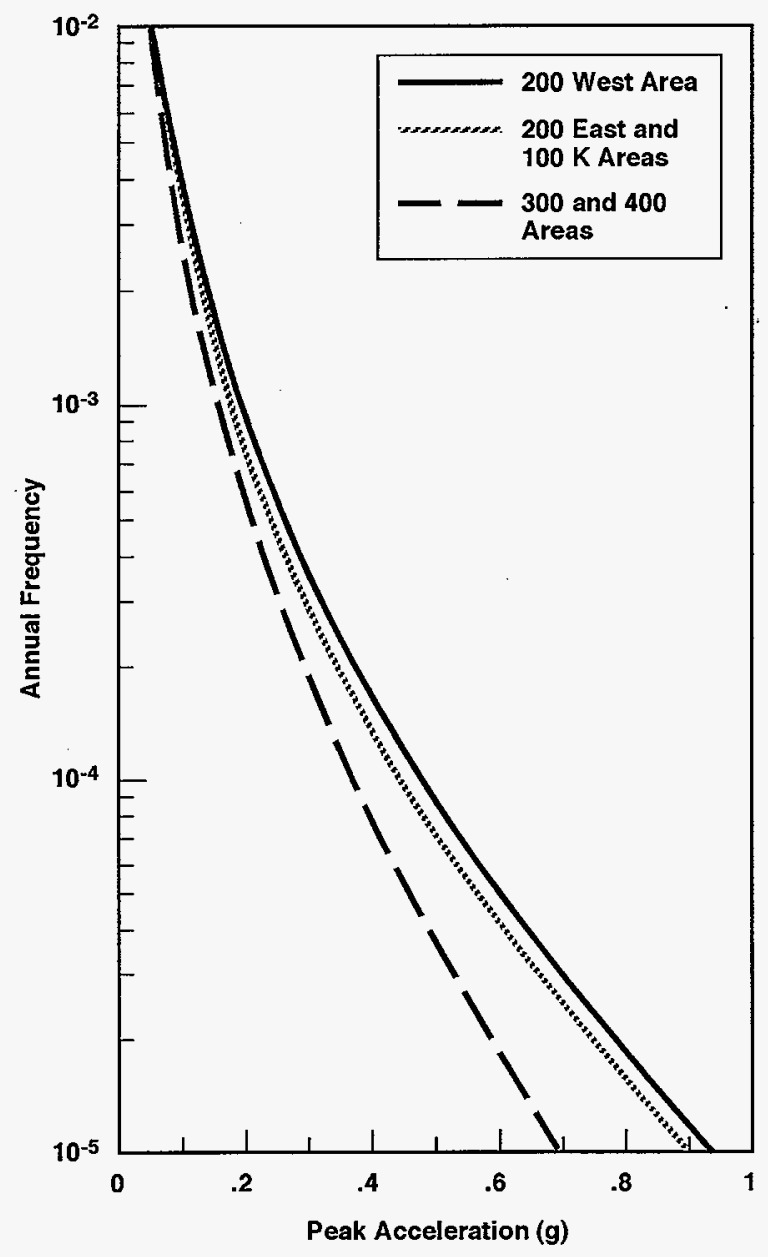

H96030114.1 
Table 1. Seismic Hazard Exceedance Probabilities.

\begin{tabular}{|c|c|c|}
\hline Performance Category & Exceedance Probability & Return Period (yr) \\
\hline 1 & $2 \times 10^{-3}$ & 500 \\
\hline 2 & $1 \times 10^{-3}$ & 1,000 \\
\hline 3 & $5 \times 10^{-4}$ & 2,000 \\
\hline 4 & $1 \times 10^{-4}$ & 10,000 \\
\hline
\end{tabular}

Horizontal and vertical equal-hazard response spectra were developed for each of the five Hanford Site areas. These are shown at 5-percent damping for the four performance categories shown in Figure 3. More detail and additional damping values are presented in Geomatrix (1996).

\subsection{WIND HAZARD}

\subsection{BACKGROUND}

The Hanford Site is located in a semiarid region of south-central Washington State. The Cascade Range to the west greatly influences the climate of the Hanford Site by causing a "rain shadow" effect. The Cascades also serve as a source of cold air drainage, which greatly affects the wind regime of the Hanford Site.

Data have been collected since 1945 at the Hanford Meteorological Station, located between the Hanford Site's 200 East and West Areas. These data include information on wind velocity and direction measured from six levels on a $125 \mathrm{~m}$ (410-ft)-high tower. These data are supplemented with data collected from 26 monitoring stations on and around the Hanford Site. The most recent compilation of these data is in PNNL-11794, Hanford Site Climatological Data Summary 1997 with Historical Data (Hoitink and Burk 1998).

\subsection{WIND HAZARD ASSESSMENT}

Three probabilistic wind hazard assessments have been completed for the Hanford Site. The first assessment was completed by Lawrence Livermore National Laboratory and reported in UCRL-53526, Natural Phenomena Hazards Modeling Project: Extreme Wind/Tornado Hazard Models for Department of Energy Sites (Coats and Murray 1985). This assessment was based on more than 30 years of pre-1979 Hanford Site wind data. The results, shown in Figure 4a, were the basis for the design wind speed recommendations for the Hanford Site in DOE-STD-1020-94 (1994a), Table 3-2. The wind missiles are listed in DOE-STD-1020-94, Table 3-1. 
Figure 3. Equal-Hazard 5-Percent Damped Response Spectra for the Four DOE Performance Categories. (Horizontal spectra are shown by the higher thick lines and vertical spectra by the lower thin lines.)
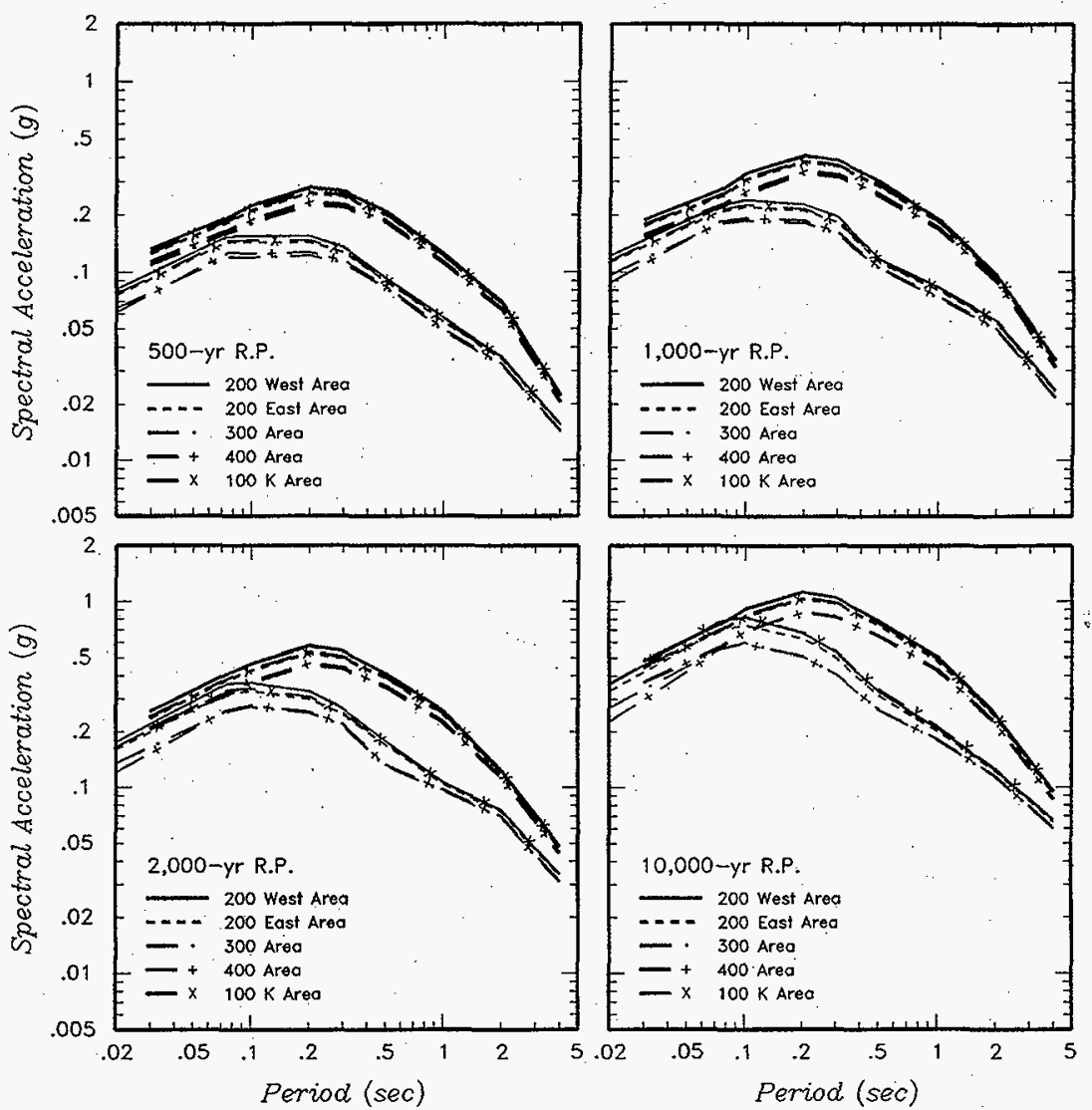
Figure 4a. Wind Hazard Curves with Design Wind Speeds. (Wind speeds are in the fastest mile.)

Wind Speed (meters/sec)

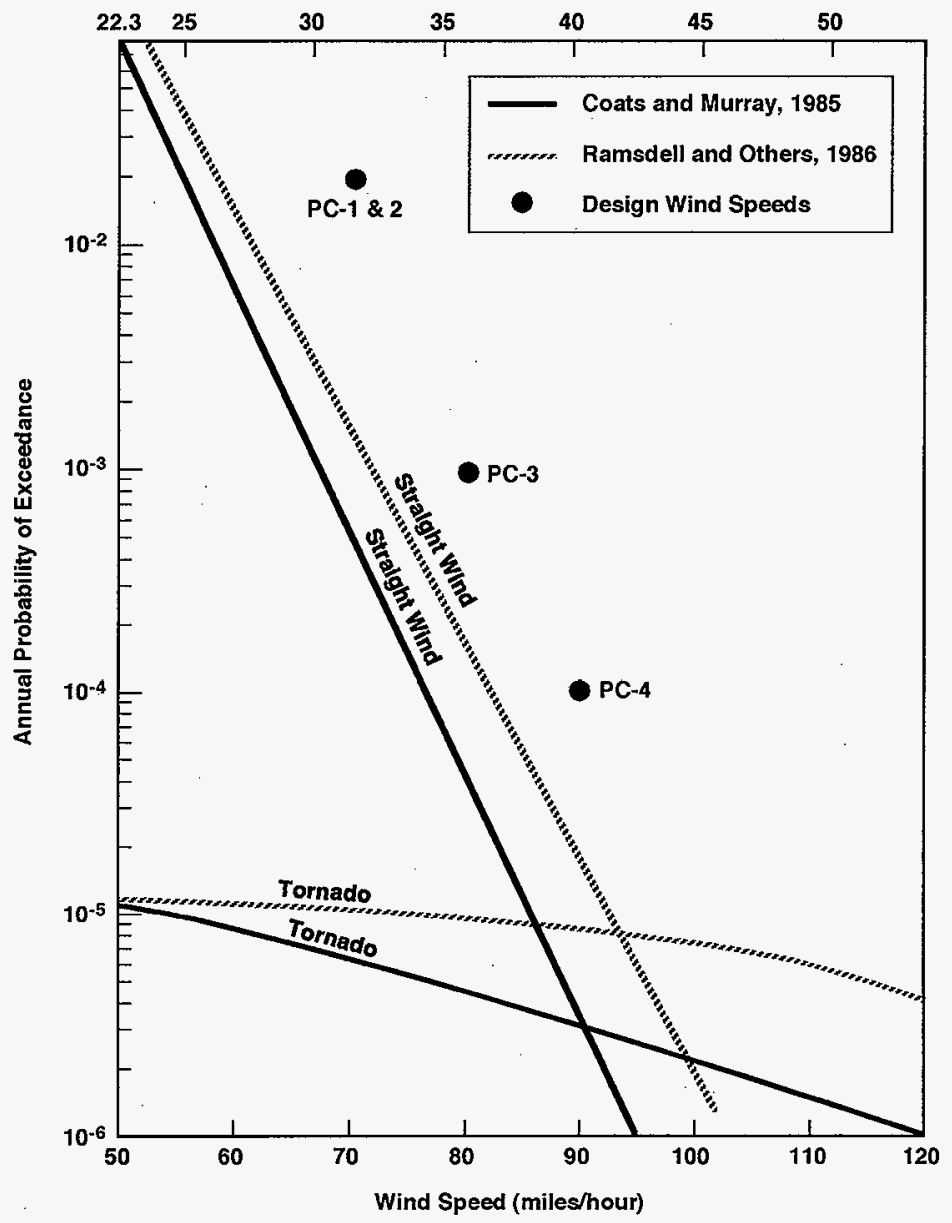

H95120284.1 
Figure 4b. Hanford Meteorological Tower Peak Gust and Extreme Wind Speed Analysis (Ramsdell 1998).

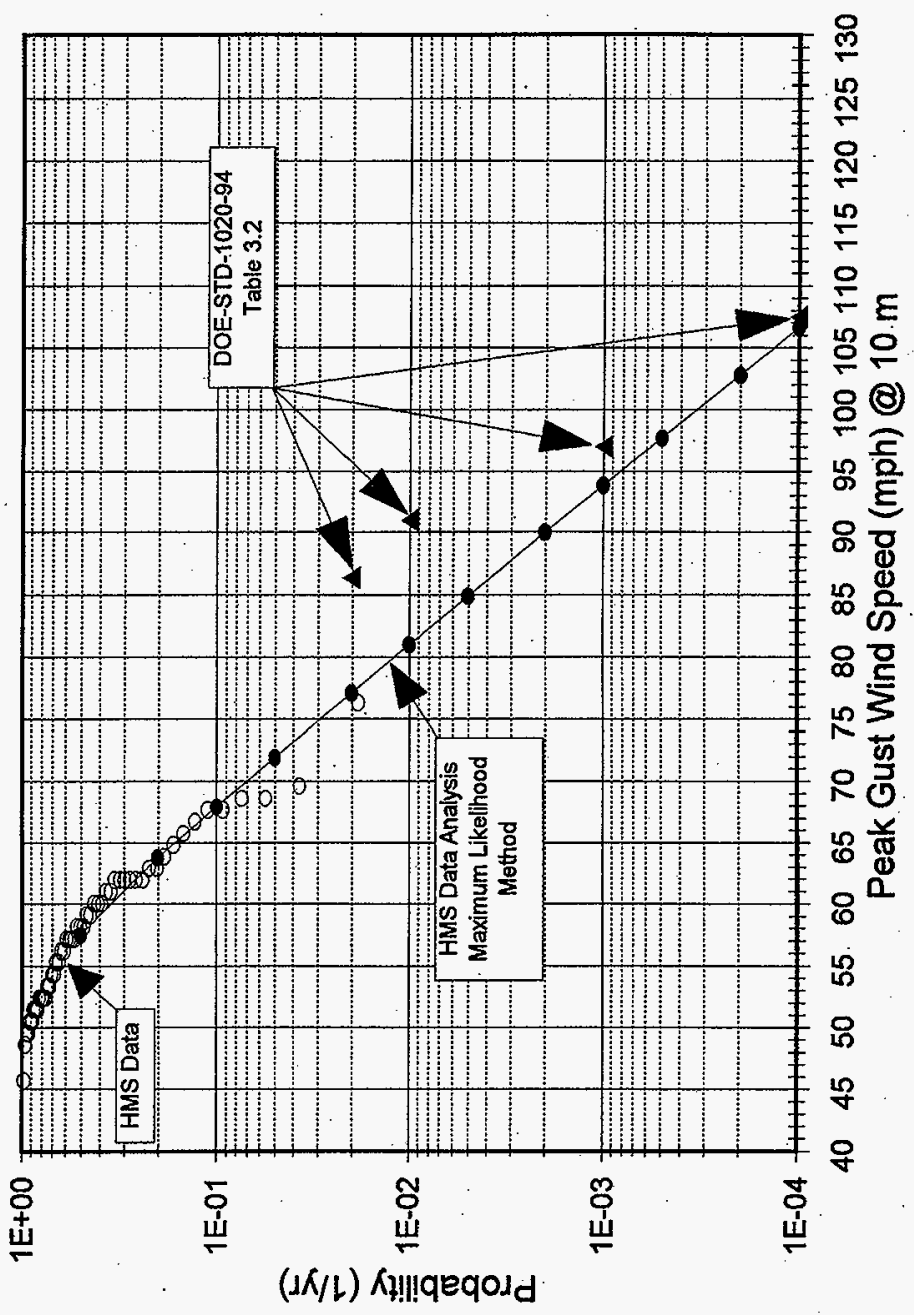


A 53-year record of peak gusts at the Hanford Site was analyzed by Ramsdell (1998) to estimate extreme wind speeds. The results of this study are summarized in Figure $4 \mathrm{~b}$. The methods used and their relationship to the work done by Peterka and Shahid (1992) supporting the ASCE 7-95 values are discussed in detail in Ramsdell (1998).

\subsection{DESIGN-BASIS WIND}

The design-basis wind speeds at the Hanford Site, shown in Figure 4a, are based on guidance found in DOE-STD-1020-94 (1994a). The recommended minimum design-basis wind speeds and the mean annual exceedance probability for each performance category are shown in Table 2. All minimum recommended wind speeds exceed the two Hanford Site wind hazard assessments completed in the 1980s (Coats and Murray 1985 and Ramsdell et al. 1986). Therefore, the minimum values are used as the Hanford Site straight-wind criteria.

Table 2. Performance Category Wind Speeds, Hanford Site.

\begin{tabular}{|c|c|c|}
\hline $\begin{array}{c}\text { Performance } \\
\text { Category }\end{array}$ & $\begin{array}{c}\text { Minimum Wind Speed } \\
\text { (fastest-mile) }\end{array}$ & $\begin{array}{c}\text { Mean Annual } \\
\text { Exceedance Probability }\end{array}$ \\
\hline 1 & $31 \mathrm{~m} / \mathrm{s}(70 \mathrm{mi} / \mathrm{h})$ & $2 \times 10^{-2}$ \\
\hline 2 & $31 \mathrm{~m} / \mathrm{s}(70 \mathrm{mi} / \mathrm{h})$ & $2 \times 10^{-2}$ \\
\hline 3 & $36 \mathrm{~m} / \mathrm{s}(80 \mathrm{mi} / \mathrm{h})$ & $1 \times 10^{-3}$ \\
\hline 4 & $40 \mathrm{~m} / \mathrm{s}(90 \mathrm{mi} / \mathrm{h})$ & $1 \times 10^{-4}$ \\
\hline
\end{tabular}

DOE released the Interim Advisory on Straight Winds (Advisory) (DOE 1998), which included the conversion from fastest-mile to peak gust wind speeds, in accordance with ASCE 7-95. The Advisory also provided revised peak gust wind speeds for the various performance category mean annual exceedance probabilities. The recommendations for lower probability wind speeds were based on generic conversion factors from Table C6-5 of ASCE 7-95, not on the site-specific wind hazard estimates. The recommendations for Performance Categories 3 and 4 are higher than current criteria and also exceed the Ramsdell (1998) study.

Work done by Peterka and Shahid (1992) was the basis for the ASCE 7-95 wind speed recommendations. Wind data from the Hanford Site were not included in their analysis. The results of the Hanford Site data analysis (Ramsdell 1998) show that the design wind speeds recommended in the Advisory (1998) and ASCE 7-95 are excessive for the Hanford Site.

The fastest-mile design wind-speeds at the Hanford Site are converted to peak gust wind speeds (Simiu and Scanlin 1996) and shown in Figure 4b. The design peak-gust wind speeds for Performance Category 1 are the same as those recommended in the Advisory. The Advisory increased the Performance Category 2 wind speed recommendation by 1.07 and reduced the importance factor from 1.07 to 1.0 , resulting in no net change. 
Based on the results of Ramsdell (1998) (Figure 4b), the DOE-STD-1020-94 (1994a) fastest-mile wind-speeds converted to peak gust for current straight wind are appropriate to use as the design criteria. The Performance Category 3 and Performance Category 4 values are conservatively rounded up to the nearest 5 . The peak gust design criteria for Performance Categories 1 through 4 are shown in Table 3.

Table 3. Straight Wind Design Criteria Measured as Peak Gusts.

\begin{tabular}{|c|c|c|}
\hline $\begin{array}{c}\text { Performance } \\
\text { Category }\end{array}$ & $\begin{array}{c}\text { Minimum Wind Speed } \\
\text { (fastest-mile) }\end{array}$ & $\begin{array}{c}\text { Mean Annual } \\
\text { Exceedance Probability }\end{array}$ \\
\hline 1 & $38 \mathrm{~m} / \mathrm{s}(85 \mathrm{mi} / \mathrm{h})$ & $2 \times 10^{-2}$ \\
\hline 2 & $40 \mathrm{~m} / \mathrm{s}(91 \mathrm{mi} / \mathrm{h})$ & $1 \times 10^{-2}$ \\
\hline 3 & $44 \mathrm{~m} / \mathrm{s}(100 \mathrm{mi} / \mathrm{h})$ & $1 \times 10^{-3}$ \\
\hline 4 & $49 \mathrm{~m} / \mathrm{s}(110 \mathrm{mi} / \mathrm{h})$ & $1 \times 10^{-4}$ \\
\hline
\end{tabular}

The intersection of the straight-wind and tornado hazard curves determines whether tornadoes should be included in the design and evaluation criteria (Coats and Murray 1985). If the exceedance probability at the intersection is less than $2 \times 10^{-5}$, straight winds control the design criteria. In Figure $4 a$, this intersection is at $3 \times 10^{-6}$ (Coats and Murray 1985) and $8 \times 10^{-6}$ (Ramsdell et al. 1986). Therefore, following DOE guidance, the Hanford Site does not have a DOE design-basis tornado.

\subsection{VOLCANIC ASH CRITERIA}

\subsection{BACKGROUND}

Two types of volcanic hazards have affected the Hanford Site in the past 20 million years:

- Continental flood basalt volcanism that produced the Columbia River Basalt Group, which underlies the Hanford Site, outcropping in the surrounding ridges

- Volcanism associated with the Cascade Range.

Several volcanoes in the Cascade Range currently are considered to be active, but activity associated with flood basalt volcanism has ceased.

The flood basalt volcanism that produced the Columbia River Basalt Group occurred between 17 million and 6 million years before present (BP). Most of the lava was extruded during the first 2 to 2.5 million years of the 11 -million-year volcanic episode. Volcanic activity has not recurred during the last 6 million years, suggesting that the tectonic processes that created the episode have ceased. The recurrence of Columbia River basalt volcanism is not considered to be a credible volcanic hazard (DOE 1988). 
Volcanism in the Cascade Range has been active throughout the Pleistocene Epoch (approximately 2 million years BP to 10,000 years BP) through the Holocene Epoch $(10,000$ years BP to present). The eruption history of the Holocene best characterizes the most likely types of activity in the next 100 years. Many of the volcanoes have been active in the last 10,000 years, including Mount Mazama (Crater Lake) and Mount Hood in Oregon, and Mount St. Helens, Mount Adams, and Mount Rainier in Washington State (Figure 5). The Hanford Site is approximately $150 \mathrm{~km}$ from Mount Adams, $175 \mathrm{~km}$ from Mount Rainier, and $200 \mathrm{~km}$ from Mount St. Helens, the three closest active volcanoes. At these distances, tephra (ash) is the only hazard. Mount St. Helens has been considerably more active throughout the Holocene than Mount Rainier or Mount Adams, which is the least active of the three.

\subsection{VOLCANIC ASH HAZARD ASSESSMENT}

Probabilistic volcanic hazard studies of the Cascade Range have been completed by the U.S. Geological Survey (Hoblitt et al. 1987, Scott et al. 1995). Figure 5 illustrates the annual probability of exceeding $1 \mathrm{~cm}$ of volcanic ash accumulation in Washington and Oregon following the eruption of a major Cascade Range volcano, and Figure 6 illustrates the annual probability of exceeding $10 \mathrm{~cm}$ of volcanic ash accumulation. The exceedance probabilities for $1 \mathrm{~cm}$ and $10 \mathrm{~cm}$ plotted in Figure 6 are from Scott et al. (1995) and are an order of magnitude lower than those from the older study (Hoblitt et al. 1987). Only Hoblitt et al. (1987) assigned a probability of exceedance for $100 \mathrm{~cm}$ of ash. The probability of exceeding $100 \mathrm{~cm}$ of ash was lowered by one order of magnitude, consistent with comparisons at 1 and $10 \mathrm{~cm}$. Figure 7 presents this information as a volcanic ash hazard curve for the Hanford Site.

\subsection{DESIGN-BASIS ASH FALL}

A study was performed to develop ashfall hazard probabilities for use in design and evaluation of structural elements subjected to ashfall loads at the Hanford Site (Salmon 1996). The design ashfall loads are presented in Table 4 . The ash load is determined by reading the depth of ash at the appropriate ash-hazard probability and assuming a 50-percent compaction ratio and an uncompacted ash density of $769 \mathrm{~kg} / \mathrm{m}^{3}\left(48 \mathrm{lb} / \mathrm{ft}^{3}\right)$

Table 4. Design-Basis Loads from Ashfall Criteria.

\begin{tabular}{|c|c|c|c|c|c|}
\hline $\begin{array}{c}\text { Performance } \\
\text { Category }\end{array}$ & $\begin{array}{c}\text { Target } \\
\text { Performance Goal } \\
\left(\mathrm{P}_{\omega}\right)\end{array}$ & $\begin{array}{c}\text { Hazard Curve } \\
\text { Slope Parameter } \\
\left(\mathrm{A}_{R}\right)\end{array}$ & $\begin{array}{c}\text { Risk Reduction } \\
\text { Factor }\end{array}$ & $\begin{array}{c}\text { Ash Hazard } \\
\text { Probability }\left(\mathrm{P}_{\mathrm{n})}\right.\end{array}$ & $\begin{array}{c}\text { Design } \\
\text { Ashfall Load } \\
\left(\mathrm{kg} / \mathrm{m}^{2}\right)\end{array}$ \\
\hline 1 & $1 \times 10^{-3}$ & 5.0 & 2.1 & $2.1 \times 10^{-3}$ & $14.6 \mathrm{~kg} / \mathrm{m}^{2}$ \\
\hline 2 & $5 \times 10^{-4}$ & 5.0 & 2.1 & $1.05 \times 10^{-3}$ & $24.4 \mathrm{~kg} / \mathrm{m}^{2}$ \\
\hline 3 & $1 \times 10^{-4}$ & 3.1 & 3.0 & $3.0 \times 10^{-4}$ & $61 \mathrm{~kg} / \mathrm{m}^{2}$ \\
\hline 4 & $1 \times 10^{-5}$ & 2.0 & 4.3 & $4.3 \times 10^{-5}$ & $146.5 \mathrm{~kg} / \mathrm{m}^{2}$ \\
\hline
\end{tabular}


Figure 5. Annual Probability of $1 \mathrm{~cm}$ or More of Volcanic Ash Accumulation in Washington and Oregon from Major Cascade Volcanoes.

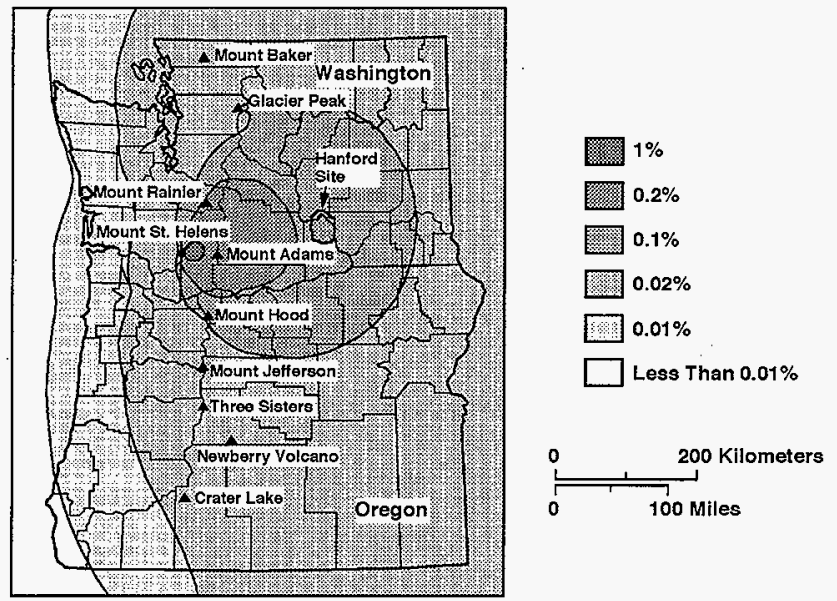

Figure 6. Annual Probability of $10 \mathrm{~cm}$ or More of Volcanic Ash Accumulation in Washington and Oregon from Major Cascade Volcanoes.

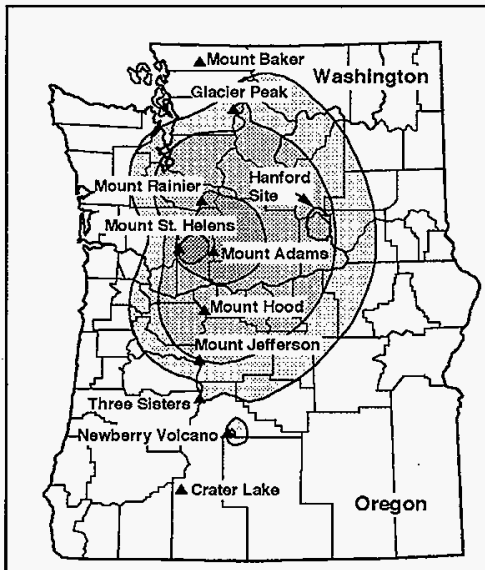

H96010294.1

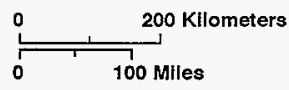


HNF-SD-GN-ER-501, Rev. 1

Figure 7. Cascade Range Volcanic Ash Hazard.

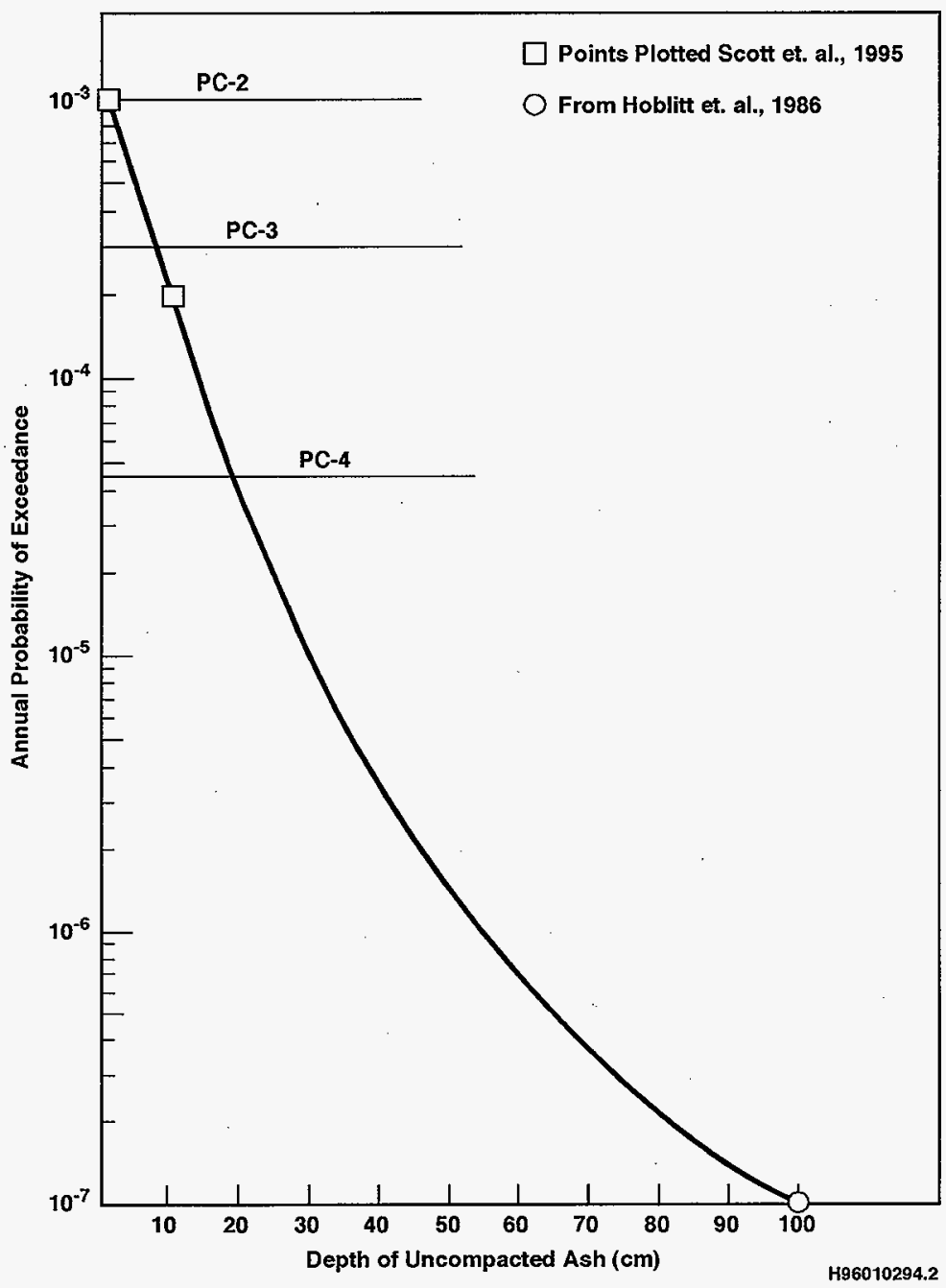


Operations that require air filtration or heating, ventilation, or air conditioning throughout an ashfall event must consider the impact of suspended ash on the operation. Unlike most other NPHs, some level of warning precedes volcanic hazards, especially distal ashfall. First, seismic activity at the volcano almost always increases from days to years before large eruptions. Further, heat gradients often increase, steam and smaller eruptions may be emitted from the volcano, and measurable deformation may occur on the volcano's surface. All these warnings provide a general alert and increase emergency preparedness in the immediate area of the volcano as well as downwind in an area like the Hanford Site. Second, it would take approximately 2 hours for ash from the closest active volcanoes to reach the Hanford Site. This shorter warning time is for the much higher probability that the ash will affect the Site. This warning lends itself to administrative controls for ashfall mitigation. Administrative procedures implemented after an eruption should be used when mitigation can be achieved through evacuation; reconfiguration of the structure, system, or component; shutdown of the operation; or other activities appropriate for the specific facility or operation. Should it be determined that a safe configuration cannot be achieved during the 2-hour warning time preceding the ashfall, the appropriate suspended ash load will be determined.

\subsection{FLOOD HAZARD}

\subsection{BACKGROUND}

The Columbia River, the second largest river in the contiguous United States in terms of flow, is the dominant surface-water body on the Hanford Site (Figure 1). The Yakima River flows along a short section of the southern boundary of the Site. Cold Creek and Dry Creek, located in the southwestern part of the Site, are ephemeral streams in the Yakima River drainage basin.

\subsection{FLOOD HAZARD ASSESSMENT}

Both river flooding and local storm runoff must be addressed in the assessment of Hanford Site flood hazards. Each hazard is discussed separately in the following sections.

\subsubsection{Local Storm Flood Hazard}

A recent cooperative study by the National Oceanic and Atmospheric Administration, the Bureau of Reclamation, and the U.S. Army Corps of Engineers has updated the probable maximum precipitation (PMP) estimates for the Pacific Northwest (Hansen et al. 1994). This document supersedes earlier work done by these organizations and is the source used for the PMP shown in Table 5. The PMP values are estimates of the maximum precipitation physically possible for both general storms (large air mass interactions) and local storms (unstable air, thunderstorms). At the Hanford Site the 6-hour local storm produces more precipitation than the 24-hour general storm. The 6-hour local storm PMP is related to the area of the storm, the 
smaller area yielding the most intense storm and highest precipitation. Data are presented for the $1-\mathrm{mi}^{2}$ and the $10-\mathrm{mi}^{2}$ storm. No annual probability of exceedance is given in Hansen et al. (1994) for the PMP for either general or local storms. The PMP is conservatively assumed to have an annual probability of exceedance of less than $1 \times 10^{-6}$ (ASCE 1988).

The 6-hour PMP for more frequent storms shown in Table 5 is from Stone et al. (1972) and is based on the analysis of extreme values from 22 years of meteorological data from the Hanford Site. The precipitation estimates for the 100- and 1,000-year return period are based on data from the Hanford Meteorology Station near the 200 West Area and include the frequency of precipitation at one location for both general and local storms. Although these values cannot be compared directly with either the $1-\mathrm{mi}^{2}$ storm or the $10-\mathrm{mi}^{2} \mathrm{storm}$, they provide a data-based estimate for extreme precipitation on the 200 Area Plateau. A 6-hour precipitation hazard curve is estimated using the 100-year and 1,000-year average return period values $\left(10^{-2}\right.$ and $10^{-3}$ annual probability exceedance respectively) from Stone et al. (1972) and the 6-hour PMP at an assumed frequency of $10^{-6}$ (Figure 8 ). The maximum daily precipitation recorded at the Hanford Site meteorological station was $4.1 \mathrm{~cm}$ in 1957 (Hoitink and Burk 1994).

\subsubsection{River Flood Hazard}

Columbia River. The free-flowing portion of the Columbia River flows through the Hanford Site and forms part of its eastern boundary. This section of the river, the Hanford Reach, extends from Priest Rapids Dam to the headwaters of Lake Wallula, which is the reservoir behind McNary Dam. The Columbia River originates in the mountains of eastern British Columbia, Canada, and drains an area of approximately $70,800 \mathrm{~km}^{2}\left(27,300 \mathrm{mi}^{2}\right)$ en route to the Pacific Ocean. Flow on the Columbia River is regulated by seven upstream dams in the United States and several in Canada. The three dams with the largest reservoirs upstream from the Hanford Site are: Mica and Hugh Keenleyside (formerly Arrow Dam) in Canada and Grand Coulee in the United States. The controlled flow of the Columbia River caused by these dams results in a lower flood hazard in the relatively high-probability floods (e.g., 100-year flood). However, for very-low-probability floods, dam-failure scenarios are significant contributors and result in an extremely high hazard.

A probabilistic flood hazard assessment of the Columbia River was performed as part of a safety evaluation of the Hanford Site N Reactor (McCann and Boisonnade 1988). The most extreme floods on the Columbia River occur as a result of dam failure. Specifically, failure of Grand Coulee and Mica dams poses the greatest threat. The results of this assessment show that the greatest contribution to the likelihood of flooding is dam failure initiated by seismic events. Conservative estimates of the seismic capacity of upstream dams were based primarily on engineering judgment. Further, the likelihood of random dam failure was based primarily on engineering judgment and the historic frequency of dam failures. See McCann and Boisonnade (1988) for a detailed discussion of the hazard assessment. 
Table 5. Extreme Precipitation Estimates for the Hanford Site.

\begin{tabular}{|c|c|c|c|c|c|c|}
\hline Time & $\begin{array}{c}\text { PMP } \\
24 \text {-hour } \\
\text { general } \\
\text { storm } \\
\left(10 \mathrm{mi}^{2 \mathrm{a}}\right)\end{array}$ & $\begin{array}{c}\text { PMP } \\
\text { local } \\
\text { storm } \\
\left(1 \mathrm{mi}^{2 \mathrm{a}}\right)\end{array}$ & $\begin{array}{c}\text { PMP } \\
\text { local } \\
\text { storm }\left(10 \mathrm{mi}^{2 a}\right)\end{array}$ & $\begin{array}{c}\text { 25-year } \\
\text { average } \\
\text { return } \\
\text { period }\end{array}$ & $\begin{array}{c}\text { 100-year } \\
\text { average } \\
\text { return } \\
\text { period }\end{array}$ & $\begin{array}{c}\text { 1,000-year } \\
\text { average } \\
\text { return } \\
\text { period }^{\mathrm{b}}\end{array}$ \\
\hline 15 minutes & -- & 4.0 & 3.2 & -- & -- & -- \\
\hline 20 minutes & -- & -- & -- & 0.47 & 0.60 & 0.80 \\
\hline 30 minutes & -- & 6.0 & 4.8 & -- & -- & -- \\
\hline 45 minutes & -- & 7.2 & 5.8 & -- & -- & - \\
\hline 1 hour & 1.6 & 8.0 & 6.4 & 0.62 & 0.81 & 1.11 \\
\hline 6 hours & 4.7 & 9.2 & 7.4 & 1.21 & 1.59 & 2.20 \\
\hline 24 hours & 8.0 & -- & -- & 1.56 & 1.99 & 2.68 \\
\hline 48 hours & 9.6 & -- & -- & - & -- & - \\
\hline 72 hours & 10.4 & -- & -- & - & -- & - \\
\hline
\end{tabular}

Note: Precipitation depths are in inches. To convert to centimeters, multiply by 2.54 .

${ }^{a}$ Hansen, E. M., D. D. Fenn, P. Corrigan, Vogel, L. C. Schreiner, and R. W. Stodt, 1994, Probable Maximum Precipitation - Pacific Northwest States, Hydrometeorological Report No. 57, National Weather Service, Silver Spring, Maryland.

${ }^{b}$ Stone, W. A., J. M. Thorp, O. P. Gifford, and D. J. Hoitink, 1983, Climatological Summary for the Hanford Site, PNL-4622, Pacific Northwest Laboratory, Richland, Washington.

$\mathrm{PMP}=$ probable maximum precipitation 
Extreme flooding on the Columbia River also can occur during extreme meteorologic and hydrologic events. Historically, the largest floods have occurred when rapid snow melt is accompanied by spring rain and frozen ground. Such floods are controlled by the dam system and are predicted to be less severe than comparable pre-dam record floods.

The probabilistic flood hazard curve at the N Reactor is presented in Figure 9. The curve shows the annual frequency of exceeding flood elevations above mean sea level. The maximum historical flood occurred in 1894, with a peak discharge of about $21,000 \mathrm{~m}^{3} / \mathrm{sec}$. The 500 -year unregulated flood-discharge at Priest Rapids is equivalent to the 1894 flood (COE 1989). The regulated 500-year flood, appropriate for dam-controlled flow, is $15,300 \mathrm{~m}^{3} / \mathrm{sec}$. Section 5.3 .2 covers the river rating curves used to determine the elevation at appropriate probabilities along the Columbia River.

Yakima River. The Yakima River borders the southern boundary of the Hanford Site (Figure 1). The head of the Yakima River is in the Cascade Range. As for the Columbia River, flooding generally occurs when rapid snow melt accompanies rain. The western third of the Hanford Site is part of the Yakima River drainage basin. Probabilistic flood hazard analysis has not been done for the Yakima River. Extremely low-probability flooding $\left(10^{-4}\right.$ and $\left.10^{-5}\right)$ by the Yakima River is expected to affect only the southernmost part of the Hanford Site where the major impact is expected to be road closures between the Tri-Cities/Benton City area and the Site. The exception may be the flooding of parts of the $700,1100,3000$, and perhaps the 300 Areas. Such flooding is covered by Columbia River scenarios.

Cold Creek. The Cold Creek watershed, located in the southwestern portion of the Hanford Site, extends about $16 \mathrm{~km}$ (10 mi) up the Cold Creek and Dry Creek Valleys. A flood risk analysis of Cold Creek was conducted in 1980 (Skaggs and Walters 1981) to determine the PMF for the Cold Creek System (Figure 10). The recurrence interval is not estimated for this flood, however each occurrence would be a flash flood of short duration. The PMF reaches an elevation of about $195 \mathrm{~m}(640 \mathrm{ft})$ on the southwestern portion of the 200 West Area. The maximum historical flood has not been recorded.

\subsection{DESIGN-BASIS FLOODS}

\subsubsection{Local Storm Runoff}

The precipitation amounts and rates used in the drainage design for facilities and the surrounding topography are determined based on the target performance goal or performance category of the facility. For new facilities, Performance Category 1 probability is two times the performance goal probability. The performance goal probability defines the annual rainfall probability of exceedance for Performance Categories 2, 3, and 4 (DOE-STD-1020-94). The design-basis 6-hour maximum precipitation levels, as derived from Figure 8, for the four performance categories are shown in Table 6. 
Figure 8. Extreme 6-Hour Precipitation Hazard.

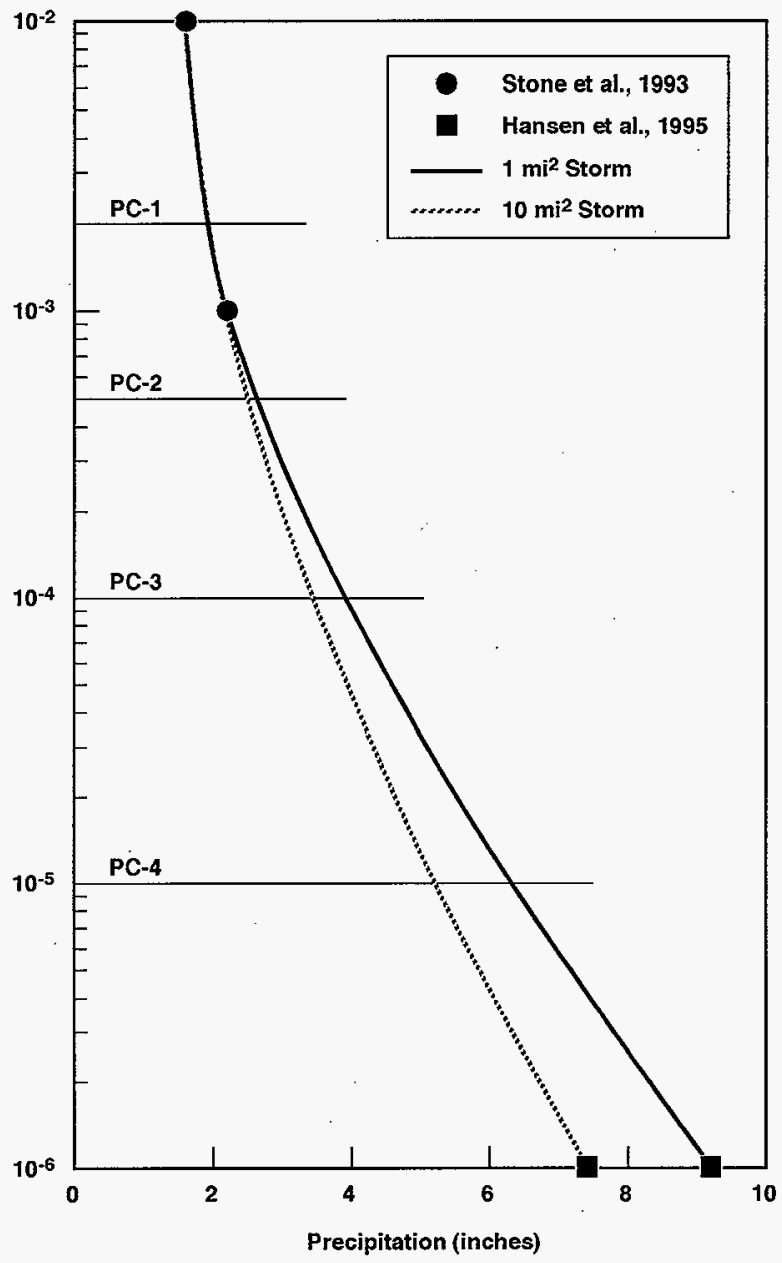

H96030064.2 
Figure 9. Fractile Hazard Curves for Peak Flood Elevation at N Reactor (McCann and Boisonnade 1988).

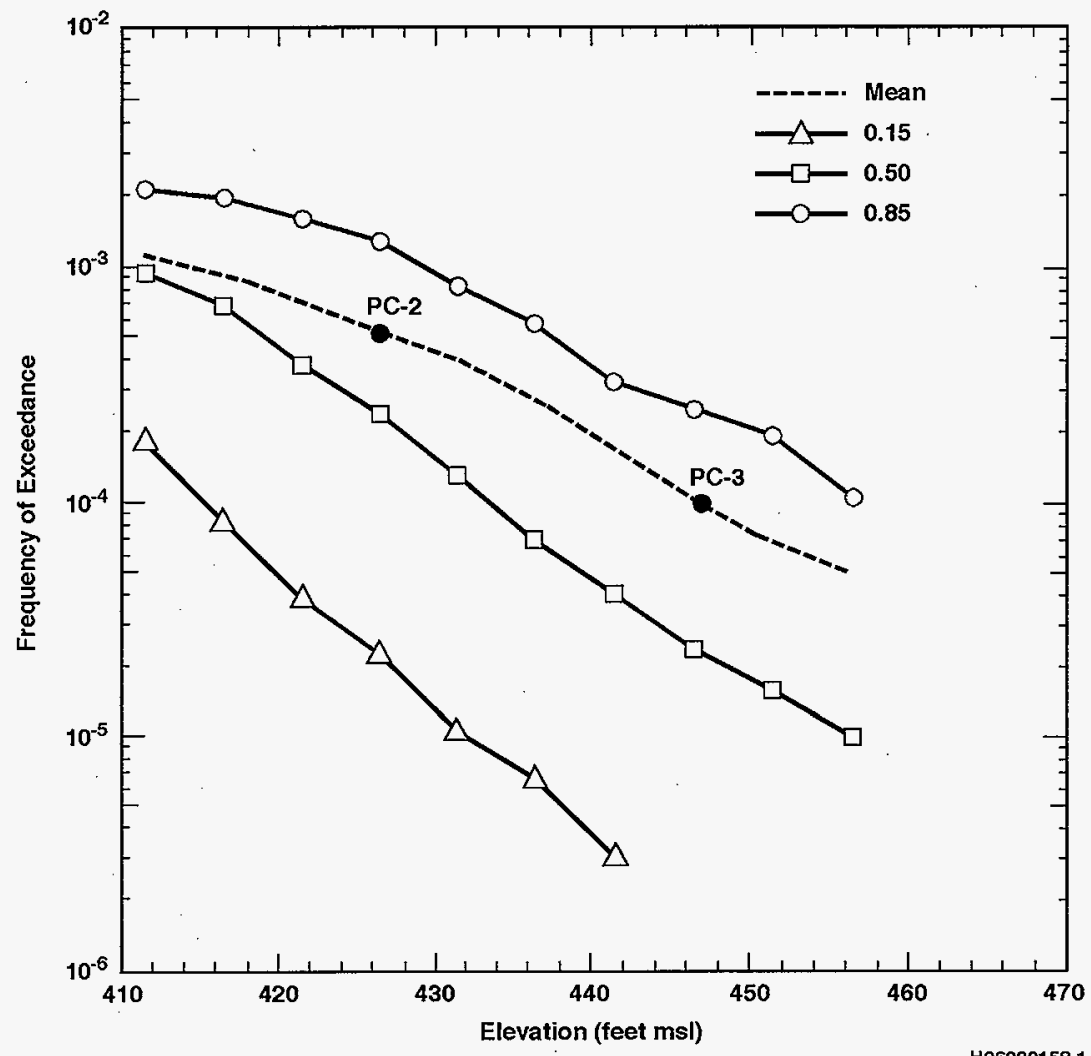


Table 6. Design-Basis Precipitation Levels.

\begin{tabular}{|c|c|c|}
\hline Performance Category & Probability & Amount (in.) \\
\hline 1 & $2 \times 10^{-3}$ & 1.8 \\
\hline 2 & $5 \times 10^{-4}$ & 2.5 \\
\hline 3 & $1 \times 10^{-4}$ & 4.0 \\
\hline 4 & $1 \times 10^{-5}$ & $6.3\left(1 \mathrm{mi}^{2}\right)$ \\
& & $5.0\left(10 \mathrm{mi}^{2}\right)$ \\
\hline
\end{tabular}

\subsubsection{Stream Flooding}

Columbia River. The Performance Category 1 flood level is based on the U.S. Army Corps of Engineers 500-year flood. The flooding hazard curve for the N Reactor (Figure 9) was used as the elevation datum for Performance Categories 2 and 3 flood hazard annual probability of exceedance. The Performance Category 4 flood level was estimated by extrapolation. The flood hazard probabilities are the same as those presented for precipitation in Section 5.3.1. The approximate elevations for each probability at the $\mathrm{N}$ Reactor are presented in Table 7 . River surface profiles developed by the U.S. Army Corps of Engineers (COE 1970) were used to extrapolate the river profile through the Hanford Site for each performance category shown in Figure 11.

Table 7. Approximate Elevations for Flooding Probabilities at N Reactor.

\begin{tabular}{|c|c|c|}
\hline Performance Category & Probability & Elevation (ft) \\
\hline 1 & $2 \times 10^{-3}$ & 395 \\
\hline 2 & $5 \times 10^{-4}$ & 426 \\
\hline 3 & $1 \times 10^{-4}$ & 447 \\
\hline 4 & $1 \times 10^{-5}$ & 475 \\
\hline
\end{tabular}

All of the 100,300,3000, and 1100 Areas are flooded at the Performance Category 4 flood levels and some of those areas are flooded at the Performance Category 3 levels. The Performance Category 3 flood level is about $3 \mathrm{~m} \mathrm{(10} \mathrm{ft)} \mathrm{lower} \mathrm{than} \mathrm{the} \mathrm{25-Percent} \mathrm{Breach} \mathrm{of}$ Grand Coulee Scenario (ERDA 1976) and Performance Category 4 is approximately the same as the 50-percent breach scenario. The Performance Category 2 level is approximately equal to the PMF. Performance Category 1 flood levels are equal to the 500-year flood and are considerably below the PMF. 
Figure 10. Extent of Probable Maximum Flood in Cold Creek Area (after Skaggs and Walters 1981).

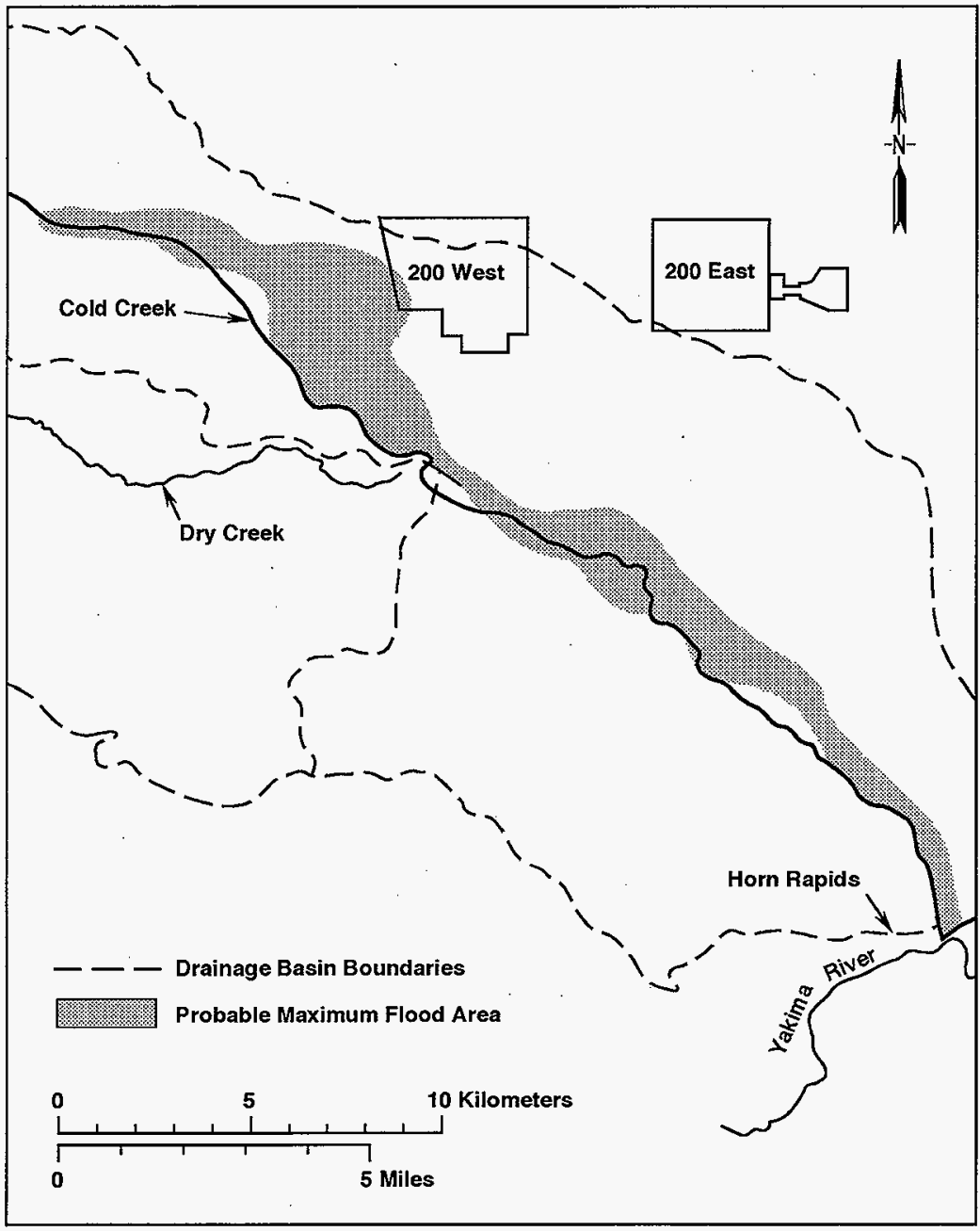

H96030114.2 
Figure 11. River Profiles for Each Performance Category.

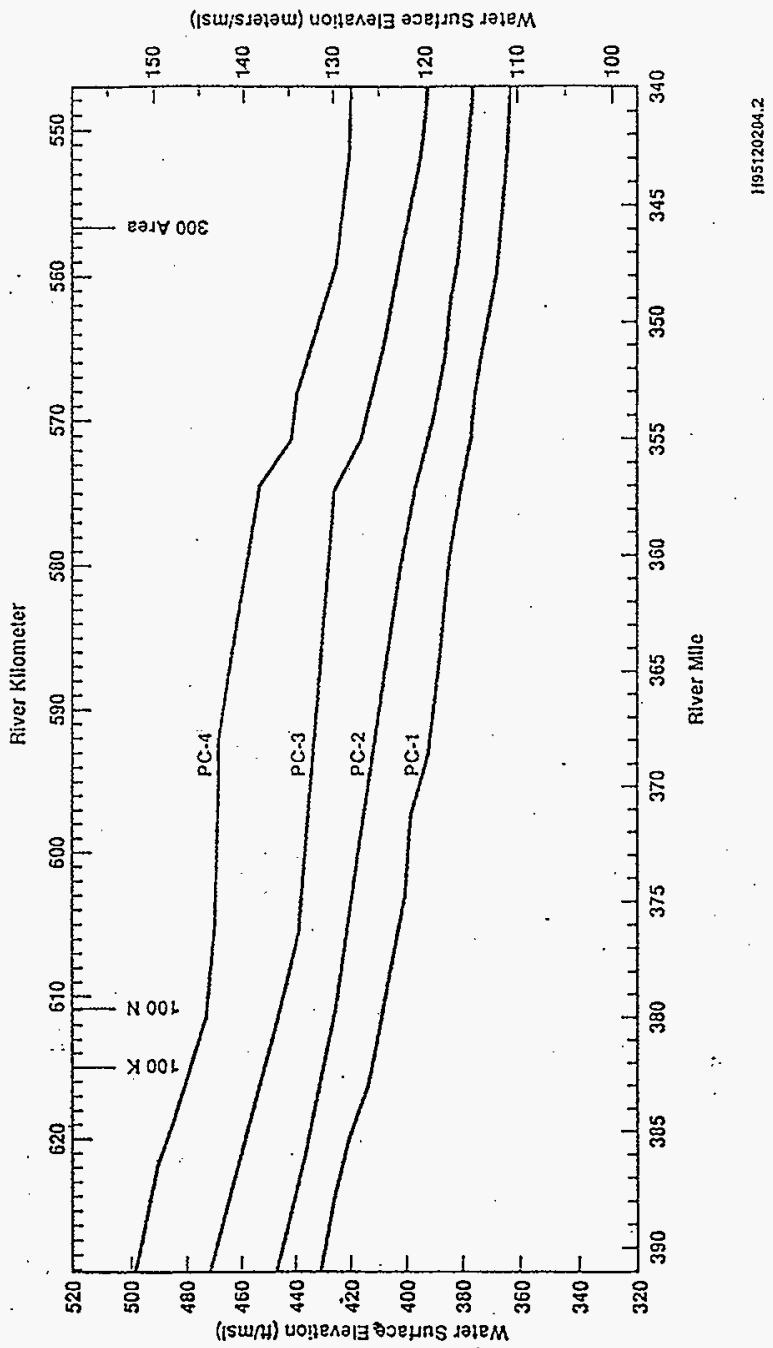


HNF-SD-GN-ER-501, Rev. 1

\subsection{SNOW LOAD}

Yakima River. No Yakima River flood criteria have been developed for the Hanford Site. No extremely low probability floods, i.e., $10^{-4}$ and $10^{-5}$ mean probability of exceedance, have been estimated. The potential flooding of the $300,700,1100$, and 3000 Areas is addressed with the Columbia River flood criteria.

Cold Creek. Based on the Cold Creek System PMF, Performance Category 2, 3, and 4 facilities should not be located below an elevation of approximately $195 \mathrm{~m}(640 \mathrm{ft})$ in the southwestern portion of the 200 Area.

\subsection{LIGHTNING}

Neither DOE nor the U.S. Nuclear Regulatory Commission has developed specific requirements for dealing with lightning. The National Fire Protection Agency (NFPA) bulletin NFPA 780, Lightening Protection (NFPA 1992), is recommended as guidance for developing lightning protection for the CSB. Both DOE and the Nuclear Regulatory Commission recommend following ASCE-7 (ASCE 1995) for ground snow loads and design guidance. At the Hanford Site, this ground snow load is $98 \mathrm{~kg} / \mathrm{m}^{2}\left(15 \mathrm{lb} / \mathrm{ft}^{2}\right)$.

\subsection{TEMPERATURE}

\subsection{AMBIENT TEMPERATURES}

The maximum ambient temperature at the Hanford Site was $46^{\circ} \mathrm{C}\left(115^{\circ} \mathrm{F}\right)$ recorded in 1939, before the establishment of the Hanford Site. The highest recorded temperature since 1945 is $45^{\circ} \mathrm{C}\left(113^{\circ} \mathrm{F}\right)$ recorded in 1961 . The lowest temperature, recorded in 1919 , is $-32^{\circ} \mathrm{C}\left(-27^{\circ} \mathrm{F}\right)$. A temperature of $-30.6^{\circ} \mathrm{C}\left(-23{ }^{\circ} \mathrm{F}\right)$ was recorded in 1950 (Stone et al. 1983 , Hoitink and Burk 1997).

Probability plots for exceeding a given temperature are presented in Figure 12 and the plots for less than a given temperature are shown in Figure 13. These plots do not include the last 17 years; however, the extreme values discussed in the previous paragraph are included. Using a graded approach for performance categories, $5 \times 10^{-4}$ for Performance Category 4 , $1 \times 10^{-3}$ for Performance Category $3,2 \times 10^{-3}$ for Performance Category 2 , and $10^{-2}$ for Performance Category 1, probabilities are used for SSC ambient temperature design criteria. The following design values are estimated from the probability plots: 
Figure 12. Highest Temperature During Each of 66 Summers of Record at the Hanford Site: 1912 through 1980 with 1943 and 1944 missing (Stone et al. 1983).

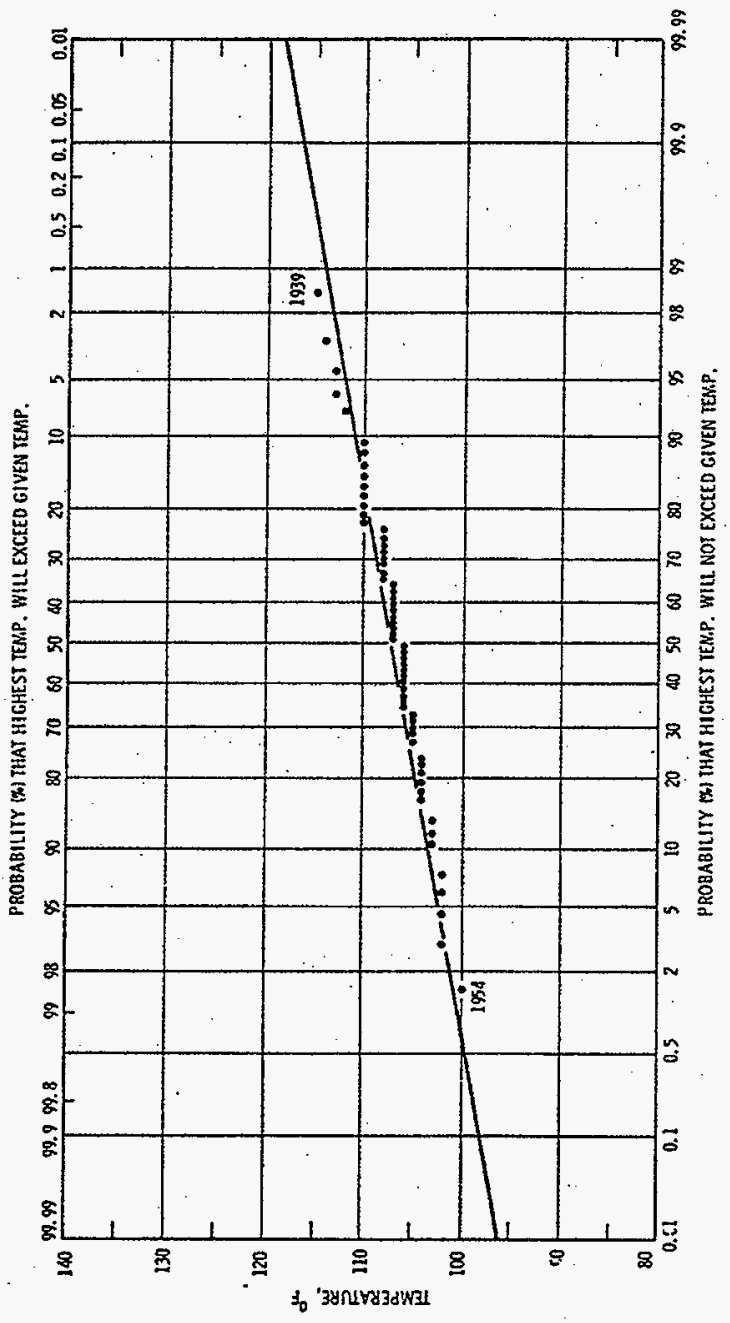


Figure 13. Lowest Temperature During Each of 68 Winters at the Hanford Site: 1912 to 1978 through 1980. Probability (Percent) that Lowest Temperature will be Higher than the Given Temperature (Stone et al. 1983).

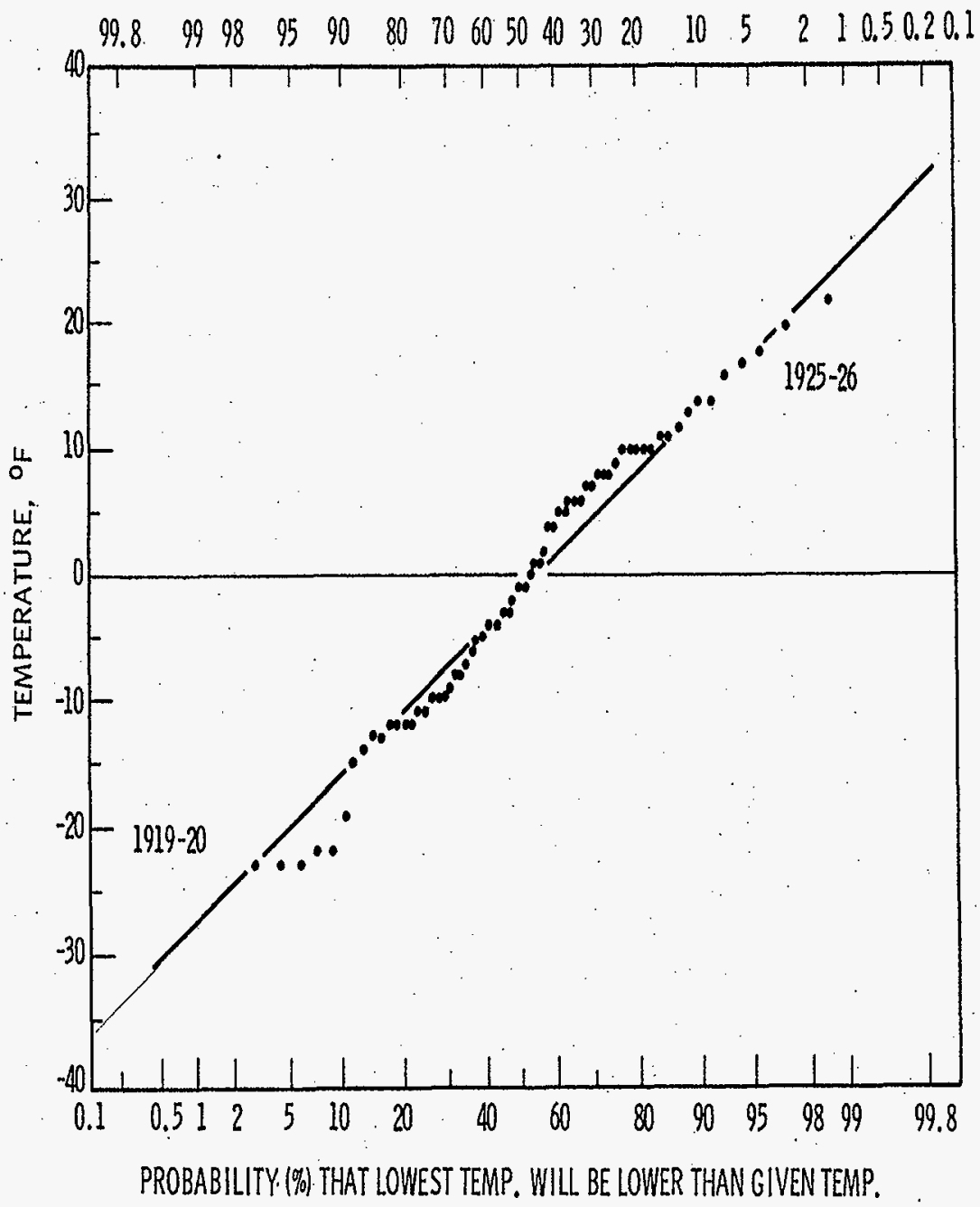


- $\quad$ Performance Category 4

- $\quad$ Performance Category 3

- $\quad$ Performance Category 2

- Performance Category 1

$$
\begin{aligned}
& 49^{\circ} \mathrm{C}\left(120^{\circ} \mathrm{F}\right) \text { to }-40^{\circ} \mathrm{C}\left(-40^{\circ} \mathrm{F}\right) \\
& 48^{\circ} \mathrm{C}\left(118^{\circ} \mathrm{F}\right) \text { to }-37^{\circ} \mathrm{C}\left(-35^{\circ} \mathrm{F}\right) \\
& 47^{\circ} \mathrm{C}\left(117^{\circ} \mathrm{F}\right) \text { to }-34^{\circ} \mathrm{C}\left(-30^{\circ} \mathrm{F}\right) \\
& 46^{\circ} \mathrm{C}\left(115^{\circ} \mathrm{F}\right) \text { to }-32^{\circ} \mathrm{C}\left(-25^{\circ} \mathrm{F}\right)
\end{aligned}
$$

Twenty-four-hour temperature ranges of greater than $4.4^{\circ} \mathrm{C}\left(40^{\circ} \mathrm{F}\right)$ have been recorded in every month except November. The SSCs should be designed to withstand a maximum 24-hour range of $28^{\circ} \mathrm{C}\left(50^{\circ} \mathrm{F}\right)$.

\subsection{SUBSURFACE TEMPERATURES}

Hourly subsurface soil temperatures have been recorded at a depth of $1.25 \mathrm{~cm}(0.5 \mathrm{in}$.) Since 1944 and at depths of $38 \mathrm{~cm}$ (15 in.) And $91.5 \mathrm{~cm}$ (36 in.) since 1952. The subsurface soil temperature sensors are installed in the natural soil of the area with the vegetation removed. The soil is a gravelly sand. Snow cover, the length and magnitude of subfreezing temperatures, and the amount of moisture in the sediment all influence the penetration of subfreezing soil conditions. The highest and lowest temperatures recorded at three depths are shown in Table 8 (Hoitink and Burk 1997, Table 3.1; Stone et al. 1983, Table 9).

Table 8. Maximum and Minimum Subsurface Temperatures at the Hanford Site.

\begin{tabular}{|l|l|l|}
\hline \multicolumn{1}{|c|}{ Depth [cm.(in.)] } & Minimum Temperature $\left[{ }^{\circ} \mathrm{C}\left({ }^{\circ} \mathrm{F}\right)\right]$ & Maximum Temperature $\left[{ }^{\circ} \mathrm{C}\left({ }^{\circ} \mathrm{F}\right)\right]$ \\
\hline $1.24(0.5)$ & $-19.4(-3)$ & $67.3(153.2)$ \\
\hline $38 \mathrm{~cm}(15)$ & $-8.8(16.1)$ & $33.9(93.0)$ \\
\hline $92.5(36)$ & $0(32)$ & $29.6(85.3)$ \\
\hline
\end{tabular}

Figure 14 (Stone et al. 1983) estimated the probability for the minimum subsoil temperature using 25 years of data. The minimum temperatures recorded through 1996 are all included in this analysis. Based on this projection, the temperature at $92.5 \mathrm{~cm}$ (36 in.) Is projected to be not less than $1.1^{\circ} \mathrm{C}\left(30^{\circ} \mathrm{F}\right)$ at extremely low probabilities. A temperature of $-12{ }^{\circ} \mathrm{C}\left(10^{\circ} \mathrm{F}\right)$ is estimated for extremely low probabilities at a minimum temperature at $38 \mathrm{~cm}$ (15 in.). The probability that subsoil temperatures will not exceed a given value at depths of $38 \mathrm{~cm}$ (15 in.) and $92.5 \mathrm{~cm}$ (36 in.) is shown in Figure 15. These values can be projected to 99 percent probability of nonexceedance.

Based on the data given in the previous paragraph, subsurface temperature design criteria are recommended in the following table. The subsurface temperature ranges are considerably less than the ambient ranges. Further, insufficient data to differentiate among extremely low probabilities. Therefore, one set of criteria is recommended for all performance categories. 
Figure 14. Annual Lowest Subsoil Temperatures (1955 Through 1980 [Stone et al. 1983]).

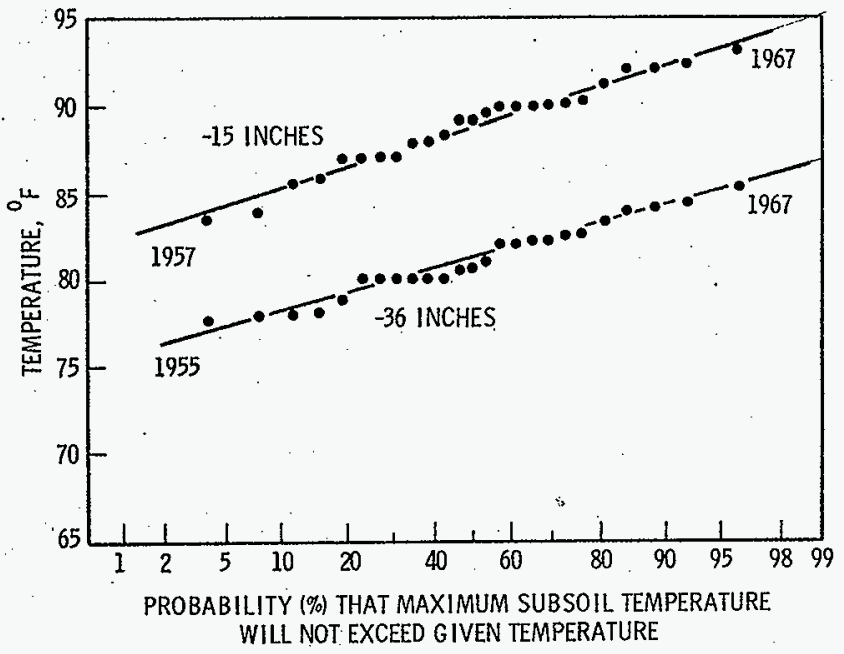

Figure 15. Probability (Percent) that Maximum Subsoil Temperature will not Exceed Given Temperature (Stone et al. 1983).

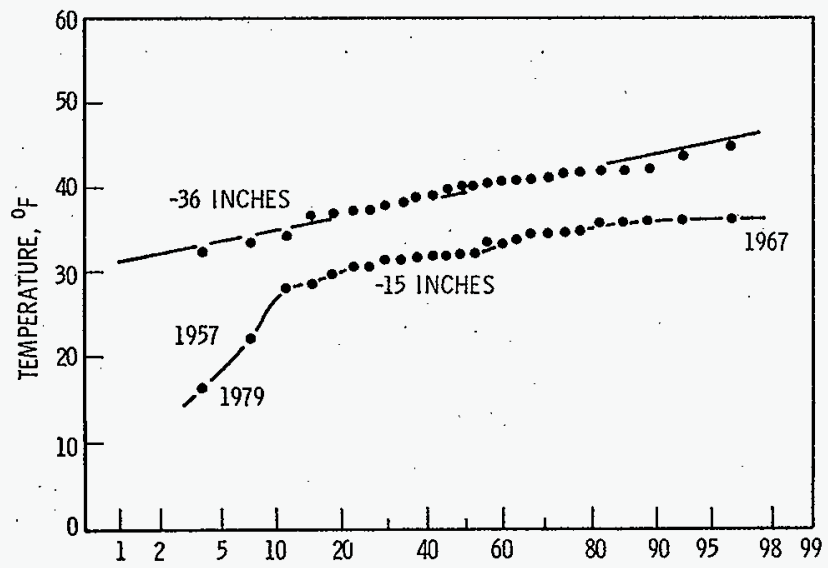

PROBABILITY (\%) THAT MINIMUM SUBSOIL TEMPERATURE WILL BE LOWER THAN GIVEN TEMPERATURE 
Subsurface SSCs should be designed for operation at the temperatures listed in Table 9 for all performance categories.

Table 9. Temperature Range for Subsurface SSC Operation.

\begin{tabular}{|c|c|}
\hline Depth [cm (in.)] & Temperature $\left[{ }^{\circ} \mathrm{C}\left({ }^{\circ} \mathrm{F}\right)\right]$ \\
\hline $1.24(0.5)$ & 71 to $32(160 \text { to } 25)^{*}$ \\
\hline $38(15)$ & 34 to $-12(95$ to 10$)$ \\
\hline $92.5(36)$ & 30 to $-1(87$ to 30$)$ \\
\hline
\end{tabular}

*The maximum temperature is based on data from a site with no vegetation or shade. The minimum temperature is considerably lower than the minimum recorded at this depth to accommodate the extreme differences in exposure and isolation at the Hanford Site.

\subsection{SOLAR RADIATION}

Average and extreme solar radiation data are available for 43 years (1953 to 1996) for the Hanford Site (Hoitink and Burke 1997). Average solar radiation is highest for July. One might expect June to have the highest solar radiation because it is the month with the most direct sunlight; however cloud cover is greater in June than in July. The highest recorded solar radiation is 838 langleys, recorded in May 1997.

All SSCs should be capable of operation in a solar radiation environment of 900 langleys. Additional detailed information is required for the design of solar energy systems.

\subsection{ATMOSPHERIC SAND AND DUST}

The criterion for both dust and blowing dust and sand storms is that the horizontal visibility is reduced to $9.6 \mathrm{~cm}(6 \mathrm{mi})$ or less. Dust is carried into the area from a distant source and may occur without strong winds. Both dust and blowing dust occur at the Hanford Meteorological Station with blowing dust most common. Dust or blowing dust occurs an average 5 days per year, based on data from 1945 through 1996 (Hoitink and Burk 1997). The greatest number of days of dust or blowing dust is 20 in 1980 after Mount St. Helens erupted. The fewest number of days is 0 , recorded most recently in 1987.

The MIL-STD-210C, Climatic Information to Determine Design and Test Requirements for Military Systems and Equipment, requires that systems and components "subjected to natural conditions" be designed for $177 \mathrm{mg} / \mathrm{m}^{3}$, at $3 \mathrm{~m}(3.28 \mathrm{ft})$ and a wind of $18 \mathrm{~m} / \mathrm{s}(40 \mathrm{mi} / \mathrm{hr})$. The particle size at or above $3 \mathrm{~m}(3.28 \mathrm{ft})$ is $150 \mu \mathrm{m}$ or less. 


\subsection{RELATIVE HUMIDITY}

The average relative humidity at the Hanford Site, based on hourly readings at the Hanford Site Meteorological Station is about 55 percent. However, values range from less than 20 to 100 percent. The SSCs should be designed for relative humidity of near 0 to 100 percent.

\subsection{REFERENCES}

ASCE, 1988, Evaluation Procedures for Hydrologic Safety of Dams, American Society of Civil Engineers, New York, New York.

ASCE, 1995, Minimum Design Loads for Buildings and Other Structures, ASCE-7, American Society of Civil Engineers, New York, New York.

Coats, D. W., and R. C. Murray, 1985, Natural Phenomena Hazards Modeling Project: Extreme Wind/Tornado Hazard Models for Department of Energy Sites, UCRL-53526, Rev. 1, Lawrence Livermore National Laboratory, Livermore, California.

COE, 1989, Artificial Flood Considerations for Columbia River Below Chief Joseph Dam to Richland, Washington, U.S. Army Engineer Division, North Pacific Corps of Engineers, Portland, Oregon.

COE, 1970, Columbia River, Washington, Water Surface Profiles, RM323 to RM395,

U.S. Department of the Army, Corps of Engineers, Seattle District, Seattle, Washington.

Conrads, T. J., 1997, Engineering Design and Evaluation, HNF-PRO-97, Numatec Hanford Corporation, Richland, Washington.

DOE, 1988, Site Characterization Plan, Consultation Draft, DOE/RW/0164, Vol. 1, U.S. Department of Energy, Washington, D.C.

DOE Order 5480.28, Natural Phenomena Hazards Mitigation, U.S. Department of Energy, Washington, D.C.

DOE-STD-1020-94, 1994, Natural Phenomena Hazards Design and Evaluation Criteria for Department of Energy Facilities, U.S. Department of Energy, Washington, D.C.

DOE-STD-1020-94, 1998, Interim Advisory on Straight Winds, Natural Phenomena Hazards Design and Evaluation Criteria for Department of Energy Facilities, U.S. Department of Energy, Washington, D.C. 
DOE-STD-1022-94, 1994, Natural Phenomena Hazards Site Characteristics Criteria, U.S. Department of Energy, Washington, D.C.

DOE-STD-1023-95, 1995, Natural Phenomena Hazards Assessment Criteria, U.S. Department of Energy, Washington, D.C.

ERDA, 1976, Evaluation of Potential Flooding Criteria on the Hanford Project, RLO-76-4, U.S. Department of Energy, Research and Development Agency, Washington, D.C.

Geomatrix Consultants, Inc., 1996, Probabilistic Seismic Hazard Analysis DOE Hanford Site, Washington, WHC-SD-W236A-TI-002, Rev. 1, Westinghouse Hanford Company, Richland, Washington.

Hansen, E. M., D. D. Fenn, P. Corrigan, Vogel L. C. Schreiner, and R. W. Stodt, 1994, Probable Maximum Precipitation - Pacific Northwest States, Hydrometeorological Report No. 57, National Weather Service, Silver Spring, Maryland.

Hoblitt, R. P., C. D. Miller, and W. E. Scott, 1987, Volcanic Hazards with Regard to Siting Nuclear-Power Plants in the Pacific Northwest, Open-File Report 87-297, U.S. Geological Survey, Cascades Volcano Observatory, Vancouver, Washington.

Hoitink, D. J., and K. W. Burk, 1998, Hanford Site Climatological Data Summary 1997 with Historical Data, PNNL-11794, Pacific Northwest National Laboratory, Richland, Washington.

McCann, M. W. Jr., and A. C. Boissonnade, 1988, Probabilistic Flood Hazard Assessment for the N-Reactor, Hanford, Washington, UCRL-21069, Lawrence Livermore National Laboratory, Livermore, California.

MIL-STD-201C, 1987, Climatic Information to Determine Design and Test Requirements for Military System and Equipment, U.S. Department of Defense, Washington, D.C.

NFPA, 1992, Lightning Protection, NFPA 780, National Fire Protection Agency, Washington, D.C.

Peterka, J. A., and Shahid, S., 1998, "Design Gust Wind Speeds in the United States," Journal of Structural Engineering, Volume 124, pp. 207-214.

Power, M. S., K. J. Coppersmith, R. R. Youngs, D. P. Schwartz, and F. H. Swan III, 1981, Final Safety Analysis Report WNP-2, Amendment N.18, Appendix 2.5K, "Seismic Exposure Analysis for the WNP-2 and WNP-1/4 Site," Washington Public Power Supply System, Richland, Washington.

Ramsdell, J. V., C. G. Elliott, C. G. Holladay, and J. M. Hubbe, 1986, Methodology for Estimating Extreme Winds for Probabilistic Risk Assessments, NUREG/CR-4492, 
Prepared for the U.S. Nuclear Regulatory Commission by Pacific Northwest Laboratory, Richland, Washington.

Ramsdell, J. V., 1998, Hanford Site Peak Gust Wind Speeds, prepared by Pacific Northwest National Laboratory for Numatec Hanford Corporation, Richland, Washington.

Salmon, M., 1996, Volcano Ashfall Loads for the Hanford Site, WHC-SD-GN-ER-30038, Prepared by EQE International for Westinghouse Hanford Company, Richland, Washington.

Scott, W. E., R. Iverson, M. Vallance, W. James, and W. Hildreth, 1995, Volcano Hazards in the Mount Adams Region, Washington, Open-File Report 95-492, U.S. Geological Survey, Washington, D.C.

Simiu, E., and Scanlin, R., 1996, Wind Effects on Structures, p. 69, Wiley, New York, New York.

Stone, W. A., D. E. Jenne, and J. M. Thorp, 1972, Climatography of the Hanford Area, BNWL-1605, Battelle Northwest Laboratory, Richland, Washington.

Stone, W. A., J. M. Thorp, O. P. Gifford, and D. J. Hoitink, 1983, Climatological Summary for the Hanford Site, PNL-4622, Pacific Northwest Laboratory, Richland, Washington.

WCC, 1989, Evaluation of Seismic Hazard for Non-Reactor Facilities at Hanford Reservation, Hanford, Washington, WHC-MR-0023, prepared by Woodward-Clyde Consultants for Westinghouse Hanford Company, Richland, Washington. 
HNF-SD-GN-ER-501, Rev. 1

This page intentionally left blank. 